\title{
The Effects of Government Quality on Corporate Cash Holdings
}

\section{Deqiu Chen}

University of International Business and Economics Email: nkchendq2006@uibe.edu.cn

Jason Xiao

Cardiff University, UK

Email: xiao@cardiff.ac.uk

\section{Sifei Li}

Beijing Foreign Studies University

Email: lisifei@bfsu.edu.cn

\section{Hong Zou}

City University of Hong Kong

Email: hongzou@,cityu.edu.hk

\begin{abstract}
While Stulz (2005) highlights the importance of the state expropriation agency problem and its interaction with the insider agency problem, there is limited research on how state policies shape firm policies. We test the effects of government quality on corporate cash holdings using a unique World Bank survey containing data on local government quality in China. Using single-country data enables us to have a cleaner test of the effects of law enforcement on cash holdings by effectively holding shareholder rights conferred by law constant (shareholder rights are a focus of prior international studies). We hypothesize that on the one hand, a good government refrains from expropriating firms and enables firms to hold more cash. On the other hand, a good government may help relieve financial constraints and enable firms to hold less cash - a new channel that has been neglected by the prior literature. In addition, a good government may indirectly affect cash holdings through limiting insiders' private consumption of firm resources. We find that firms hold less cash when there is a better local government, and the effect is more pronounced in private firms than in state-owned enterprises (SOEs). Our evidence suggests that the financial constraint relieving argument dominates the expropriation argument in China. Increasing external sources of finance such as bank loans, trade credit, and inward foreign direct investment are among the ways through which local governments help relieve firms' financial constraints. Our study is also the first to find evidence that supports Stulz's (2005) argument on the interaction between the twin agency problems.
\end{abstract}

\section{JEL Classification: G32; G38}

Keywords: Cash holdings; China; Government quality; Institutions; Investor protection; Twin agency problems

We appreciate the comments from Paul Brockman, Sudheer Chava, Qiang Cheng, Mark Clatworthy, Mahmoud Ezzamel, Michael Faulkender, Marc Goergen, Yuanto Kusnadi, Oliver Zhen Li, David Marginson, Ronald Masulis, William Megginson, Micah Officer, Maurice Pendlebury, Cong Wang, Yuhai Xuan and the seminar participants at Cardiff University, Peking University, and Renmin University, as well as the participants of the $23^{\text {rd }}$ Australian Finance \& Banking Conference. 


\title{
The Effects of Government Quality on Corporate Cash Holdings
}

\begin{abstract}
While Stulz (2005) highlights the importance of the state expropriation agency problem and its interaction with the insider agency problem, there is limited research on how state policies shape firm policies. We test the effects of government quality on corporate cash holdings using a unique World Bank survey containing data on local government quality in China. Using single-country data enables us to have a cleaner test of the effects of law enforcement on cash holdings by effectively holding shareholder rights conferred by law constant (shareholder rights are a focus of prior international studies). We hypothesize that on the one hand, a good government refrains from expropriating firms and enables firms to hold more cash. On the other hand, a good government may help relieve financial constraints and enable firms to hold less cash - a new channel that has been neglected by the prior literature. In addition, a good government may indirectly affect cash holdings through limiting insiders' private consumption of firm resources. We find that firms hold less cash when there is a better local government, and the effect is more pronounced in private firms than in state-owned enterprises (SOEs). Our evidence suggests that the financial constraint relieving argument dominates the expropriation argument in China. Increasing external sources of finance such as bank loans, trade credit, and inward foreign direct investment are among the ways through which local governments help relieve firms' financial constraints. Our study is also the first to find evidence that supports Stulz's (2005) argument on the interaction between the twin agency problems.
\end{abstract}

JEL Classification: G32; G38

Keywords: Cash holdings; China; Government quality; Institutions; Investor protection; Twin agency problems 


\section{Introduction}

We examine in this study whether the quality of governments affects corporate cash holdings using a unique dataset from a single country, and if yes, through which channels. Our study stands at the intersection of two important literatures, namely, the law and finance literature and the corporate cash holding literature.

Prior law and finance literature identifies government as a key institutional factor and reports that a good government helps promote a country's economic growth (Frye and Shleifer, 1997; Shleifer and Vishny, 1998; La Porta et al., 1999). Stulz (2005) advances a "twin agency" concept: in addition to company insiders' (i.e., managers and controlling shareholders) expropriation of outside minority investors (i.e., the insider agency problem), the state also uses discretionary powers to expropriate firms and their investors (i.e., the state agency problem). While his model highlights the importance of state expropriation in affecting investors' investment strategy and corporate ownership, there is little empirical evidence as to how state policies and their interaction with managerial incentives shape firm financial policies. Meanwhile, Fan et al. (2011) call for special attention to government quality in understanding firm behaviors in emerging markets because the conventional constraints of executive power are insufficient to regulate the behaviors of politicians in emerging markets.

Corporate cash holdings can be strategically important because they can significantly affect a firm's ability to take advantage of investment opportunities (Harford, 1999), can be diverted to inefficient use that generates private benefits to entrenched managers (Jensen, 1986) and/or are vulnerable to extraction (Myers and Rajan, 1998). It is therefore interesting to see how government quality affects corporate cash holding decisions. ${ }^{1}$

Corporate cash holding has received significant research attention in recent years. In

\footnotetext{
${ }^{1}$ In the spirit of La Porta et al. (1999) and Levine (2005), we define a good (high-quality) government as one that protects property rights, keeps regulations and taxes light, is clean, and provides efficient public services. We do not look at democracy and political rights as all cities in China are subject to a highly homogenous political environment.
} 
addition to the economic determinants that reflect the transactional cost motive and the precautionary motive ${ }^{2}$, agency costs of managerial discretion are identified as an important factor affecting the level of corporate cash holdings. Jensen's (1986) agency argument focuses on the shareholder-manager agency conflicts and predicts that absent monitoring managers have incentives to use free cash flow in a way that generates private benefits. As a result, shareholders discount the value of cash holdings in anticipation of such agency incentives. Consistent with this argument, Harford (1999) finds that cash-rich US firms tend to make value destroying acquisitions, and Harford et al. (2008) show that US firms whose managers are subject to less discipline have a lower level of cash holdings because they over-invest. Dittmar and Mahrt-Smith (2007) further show that investors discount the value of cash held by poorly governed US firms, which tend to spend excess cash more quickly in a non-productive way. ${ }^{3}$ Bates et al. (2009), however, find that the increase in cash holdings in US firms in recent years is not ascribed to agency problems.

Some researchers have used cross-country data in order to understand how investor protection and related agency problems affect corporate cash holdings. The efforts, however, have resulted in mixed evidence. Dittmar et al. (2003) show that firms in countries with weak shareholder rights tend to hold more cash. Pinkowitz et al. (2006) find that in countries with weak investor protection, shareholders discount corporate cash holdings more significantly. Kalcheva and Lins (2007) find that the same shareholder rights index does not have a significant effect on corporate cash holdings in their sample, but it weakens the positive relation between managerial control rights (a firm-level agency cost proxy) and cash holdings. In contrast, Caprio et al. (2010) find that it is positively related to cash holdings (after controlling for the quality of institutions) when using a UK legal origin dummy as a proxy for strong shareholder rights.

These prior cross-country studies mainly focus on the shareholder rights granted by the law. Investor protection, however, includes two components: a legal right component

\footnotetext{
${ }^{2}$ See Opler et al. (1999) and Bates et al. (2009) for a good review of these motives.

${ }^{3}$ They follow an analytical approach proposed by Faulkender and Wang (2006).
} 
that grants investors legal rights, and an enforcement component that reflects the extent to which these rights are respected and enforced by a country's institutions (e.g., the government, the court system) (Allen et al., 2005; Pinkowitz et al., 2006; Harford et al., 2008). So far, there is little evidence on how the quality of institutions or the enforcement-component of investor protection affects corporate cash holdings. 4 Recognizing this, a contemporaneous work by Caprio et al. (2010) examines the effects of both shareholder rights and the quality of institutions (proxied by indexes on law/contract enforcement and corruption) on corporate cash holdings with a cross-country sample. They find that firms hold less cash when the political extraction risk is high.

Our study takes a different approach to testing the effects of institutional quality on corporate cash holdings by using a unique intra-country dataset. Focusing on a single country affords three key advantages. First, it allows us to have a cleaner test of the enforcement-component of investor protection on corporate cash holdings by effectively holding shareholder rights conferred by law on paper constant (Harford et al., 2008). ${ }^{5}$ This separation is important given that law on paper and law enforcement can deviate significantly (Allen et al., 2007). ${ }^{6}$

Second, focusing on a single country allows us to include finer proxies for firm-level agency cost problems (i.e., the insider agency problem in the term of Stulz (2005)) that are also important in corporate cash holding decisions. In contrast, it is difficult to come up with good firm-level agency proxies in international studies (Kalcheva and Lins, 2007). For instance, due to data limitation, Dittmar et al. (2003) do not include a firm-level proxy for the insider agency problems (they use a country-level measure of family control instead). Absent information on cash flow rights, Kalcheva and Lins (2007) only proxy firm-level

\footnotetext{
${ }^{4}$ While Pinkowitz et al. (2006) also use several indexes on the quality of institutions in different countries in splitting their samples, they do not directly examine how these indexes of institutional quality affect corporate cash holdings. We use quality of institutions and the enforcement-component of investor protection interchangeably in the rest of the paper.

${ }^{5}$ Harford et al. (2008) also hold constant the country-level legal setting by focusing on US firms.

${ }^{6}$ In China, the enforcement of law on paper is also a common issue and this means that it is more important to look at law enforcement than shareholder rights on paper (Zou et al., 2008).
} 
agency problems by managerial control rights, and they are careful to note that this proxy mainly reflects insiders' capability of expropriation rather than the incentive of expropriation. In our study, we use the wedge between control rights and cash flow rights for the ultimate owner to measure the extent of incentive conflicts between controlling and minority shareholders and this proxy is appropriate in a setting where the corporate ownership structure is concentrated such as China (Lin et al.,2011).

Third, focusing on a single country enables us to avoid the many common limitations (e.g., assigning an equal weighting to large and small countries, differences in accounting and financial reporting) that often plague cross-country studies (Allen et al., 2005). Fan et al. (2011, p.207) also argue that a single-country study can "control data quality better, which enables researchers to analyze the impacts of a key institutional factor on various issues with greater depth, while holding constant other factors that might be difficult to disentangle in cross-country studies."

Of course, a potential concern for using single-country data is that there might be limited variations in the quality of government and other institutions. We mitigate this concern by choosing China that is a large and diverse country with substantial disparity in the levels of economic and institutional development (including law/contract enforcement, the effectiveness and efficiency of the judicial system, and taxation) across different regions despite the same shareholder rights conferred by uniform commercial laws on paper (Cull and Xu, 2005; Lin et al., 2010).

China is also interesting for four other reasons. First, as a large and growing economic power, China and the financing, investment and growth of Chinese companies have become a research subject in many recent studies (e.g., see Allen et al., 2005; Cull and Xu, 2005; Fan et al., 2007; Firth et al., 2008; 2009; Zou and Adams, 2008; Ayyagari et al., 2010). However, China is typically excluded from prior cross-country studies on investor protection and corporate cash holdings. As a result, we know little about this issue in China. 
Second, one stream of the economic reforms in China over the last three decades has been to decentralize administrative rights and to increase local governments' autonomy. Ayyagari et al. (2010) note that local governments in China have strong rule-making powers and can implement national laws according to their needs - in order to compete with each other to promote regional economic development (Qian and Roland, 1998) or to enable corrupt government officials to extract rents. China therefore serves as an interesting setting within which to test the effects of government quality on corporate cash holdings.

Third, corporate cash holding decisions are particularly important in China because there are various regulatory restrictions on the access to the securities market and bank loans (Xiao and Zou, 2008). Private firms should attach more importance to cash holding decisions as they are at a disadvantage in gaining access to finance provided by state-owned banks. Finally, the co-existence of SOEs and private firms enables us to investigate whether government quality has differential effects on firms with different owner identities. This further substantiates the impact of government quality on corporate cash holdings.

We hypothesize that a good government may affect corporate cash holdings in three ways. First, a good government refrains from expropriating firms and as a result, firms can hold more cash with less fear over government extraction (i.e., the expropriation argument). Caprio et al. (2010) argue that firms react to the state expropriation risk by taking actions to keep less cash in order to shelter corporate assets from expropriation. This predicts a positive relation between government quality and corporate cash holdings.

Second, a good government may help relieve financial constraints facing firms and enable them to hold less cash (i.e., the financial constraint mitigation argument). Specifically, a good government better protects property rights by enforcing law/business contracts, thereby boosting banks' confidence in lending as the chance of loan repayment and repossessing collateral increases (Ayyagari et al., 2010). Similarly, a good government will uphold contracts in business disputes and this enhances the credibility of business 
entities, thereby allowing local firms to access more trade credit financing. Moreover, being less predatory and stricter in enforcing laws and rules, a good government may also help enhance corporate governance and transparency (Stulz, 2005; Desai et al., 2007; Durnev and Fauver, 2010), which in turn lower the costs of both debt and equity financing. ${ }^{7}$ The financial constraint mitigation argument predicts a negative relation between government quality and corporate cash holdings.

Third, a good government may also indirectly affect corporate cash holdings through its interaction with the insider agency problem. A large wedge between the voting rights and cash flow rights owned by the ultimate owner generates more incentives for the controlling shareholder to expropriate outside minority investors. To the extent that cash, an anonymous and the most transportable and liquid asset, is most vulnerable to expropriation, a large ownership wedge is expected to lead the company to keep more cash to facilitate extraction. Consistent with this argument, Kalcheva and Lins (2007) find a positive relation between managerial control rights and firms' cash holdings using an international dataset. A good government better protects investors via more effective law/contract enforcement, and this increases the cost to corporate insiders of extracting private benefits (e.g., via siphoning cash) from the firms they control (Stulz, 2005). In addition, state expropriation and insiders' expropriation of private benefits often reinforce each other (Stulz, 2005), which suggests reducing state expropriation by a good government also decreases the extent of insiders' expropriation. We therefore hypothesize that government quality attenuates the positive relation between ownership wedge and corporate cash holdings.

Note that the above three effects of a good government on cash holdings are not mutually exclusive, and they could coexist to exert an influence. We rely on the empirical analysis to ascertain which effect is the dominating one. It is worth noting that, in relation to corporate cash holdings, the prior literature has mainly focused on the state expropriation argument, but has largely neglected the financial constraint mitigation argument and the

\footnotetext{
${ }^{7}$ Note this possibility also points to a form of the interaction between the state agency problem and the insider agency problem that we will discuss next.
} 
interaction between government quality and insiders' agency incentives. Uncovering these new channels and furnishing evidence on them are a key contribution of our study.

We empirically test these different predictions using a unique dataset on government quality sourced from a World Bank (2006) survey. The survey covers 12,400 firms across 120 cities in China and ranks government quality by various measures. Lin et al. (2010) use the same data in examining the effects of property rights protection on corporate $R \& D$ investment. Cull and Xu (2005) and Ayyagari et al. (2010) also use a similar but a smaller scale survey (covering 18 cities) conducted by the World Bank in early 2003 in their study of financing and investment of Chinese firms.

Measuring government quality by individual indexes on property rights protection, cleanliness and efficiency of a government, tax burden, and an aggregate of these indexes, we find robust evidence that firms hold less cash when there is a better local government. The evidence suggests that in China, the financial constraint mitigation argument dominates the expropriation argument in corporate cash holding decisions. Importantly, this result is not an artifact of differences in financial development since we control for the difference in economic and credit market development.

We validate the finding that a good government helps mitigate the financial constraints of companies by running Fazzari et al.'s (1998) investment-cash flow regression augmented by government quality and its interaction with cash flow. We find that government quality decreases the (positive) sensitivity of investment to cash flows, that is, a good government mitigates financial constraints. Recognizing the debates over Fazzari et al.'s (1998) model, we also run a regression on the cash flow sensitivity of cash in the manner of Almeida et al. (2004). This additional analysis continues to suggest that a good government lowers the (positive) sensitivity of cash to cash flows. Based on these tests, we conclude that a good government relieves companies' financial constraints and this allows local firms to hold less cash.

To better understand how a good government helps relieve a local firm's financial 
constraints, we further explore the possible channels. We conjecture that a good government better protects property rights by enforcing law/contracts, and this increases banks' confidence in making lending ex ante as the ex-post loan repayment and recovery of collateral is more certain. ${ }^{8}$ The same effect also applies to business suppliers so that they are willing to extend more trade credit to corporate purchasers from a region where there is a good government. Moreover, a good government also institutes good and investor-friendly policies that help foster a better investment climate, thereby attracting more inward foreign direct investment (FDI) (an important source of capital in China).

We regress firms' access to bank loans, trade credit (measured by accounts payables), and the amount of FDI attracted by the region on the quality of the local government controlling for other factors. We find that a better government increases all three sources of financing, and these sources of financing are negatively related to corporate cash holdings. Therefore, it appears that bank lending, trade credits, and FDI are among the channels through which a good government can improve local firms' access to external finance and/or lower their financing costs, thereby enabling local firms to hold less cash.

We also take advantage of the existence of different types of corporate ownership in China to design tests that further bolster our key finding. In China, private firms face more financial constraints than do SOEs (private firms are traditionally discriminated against in credit allocation) (Allen et al., 2005). If the effect of government quality on corporate cash holding is through relieving financial constraints, one should expect that the effect is more pronounced in private firms than in SOEs since the marginal benefit of a good government should be higher to firms that face more financial constraints. This is indeed what we find from interaction analyses. These cross-sectional differences in the government quality and corporate cash holdings not only reinforce our baseline finding, but also help mitigate the concern over the possibility that endogeneity drives our results.

Compared with studies that regress a firm-level variable on other firm-level variables,

\footnotetext{
8 This is true because in China the effectiveness of courts depends crucially on the quality of the local government given that the judicial system is not entirely independent of government administrations.
} 
endogeneity in our study should be less of a concern given that our dependent variable is at the firm level and government quality is at the city level. However, since our government quality measures are constructed from firms' perceptions averaged within the city level, we cannot rule out the chance that these government quality measures are subject to a feedback effect running from firms' financial situation (e.g., cash holdings). To address this concern, we adopt an instrumental variable estimation.

We instrument the quality of local governments by three variables taken from the World Bank report concerning the progress towards a harmonious society: green space per capita, infant mortality, days with good or excellent air quality. These variables, to a large degree, indicate the amount of effort made by local governments to improve social welfare and as a result, they are expected to be positively related to government quality. They, however, have no direct relation with corporate cash holdings unless through government quality or economic development that is already accounted for by our model. The results from a two-stage least square estimation confirm the robustness of our results.

As for the result on the interaction between the insiders' agency problem and the state agency problem, we find that a large wedge between the control rights and cash flow rights owned by the ultimate owner is associated with more cash holdings in China when government quality is below the sample median. The result is consistent with Stulz's (2005) argument on the interaction between the state agency problem and the insider agency problem, and such interaction affects firms' cash holdings. While Kalcheva and Lins (2007) are the first study to test the effect of the interaction between shareholder rights and insiders' agency problem on corporate cash holdings, our paper is the first to test the effect of the interaction between government quality and insiders' agency problem in corporate cash polices. Government quality shows a robust negative effect on firms' cash holdings regardless of the extent of ownership wedge. Therefore, government quality as an external institution-level investor protection proxy appears to have a first-order effect on corporate cash holdings. 
By showing that a good government helps relieve financial constraints facing the indigenous companies and enable them to keep less cash, our study uncovers a new channel through which institutional quality affects corporate cash holdings. Our finding differs from the positive relation between government quality and corporate cash holdings reported in Caprio et al. (2010). They use an international sample, only consider and find support for the state expropriation argument. The difference in results might be because their study is a joint test of the effects of shareholder rights and enforcement on corporate cash holdings, whereas ours is a test of the enforcement component/institution-level investor protection since we effectively hold the law-granted shareholder rights constant by using single-country data. Our study also adds to the limited research on how state policies can shape firm policies (e.g., see Durnev and Fauver, 2010).

The remainder of the paper is organized as follows. Section 2 describes data and variables used in our tests. Section 3 reports the empirical results. Section 4 presents the results of robustness checks, and Section 5 concludes the paper.

\section{Data and variables}

\subsection{Sample selection}

We obtain data on government quality from a World Bank (2006) survey report entitled "Governance, Investment Climate, and Harmonious Society - Competitiveness Enhancements for 120 Cities in China". This survey covers 12,400 firms in 120 major cities in China and provides detailed city-level data on government effectiveness and progress toward a harmonious society, among other characteristics. The 120 cities are distributed across all provinces except Tibet and their combined GDP accounts for about $80 \%$ of China's total GDP. The survey questions reflect how firms perceive the quality of the governments in 2004, and firm-level replies are then aggregated into various city-level average indexes. Please see Cull and Xu (2005), Lin et al. (2010), and Ayyagari et al. (2010) 
for further details on such World Bank surveys.

As the World Bank survey was undertaken in 2005 and collected data for 2004, we measure cash ratio, the dependent variable in our analysis for the period 2005 to 2007 . Starting from 2005 is to allow the effects of government quality to show up in future corporate cash holding decisions. Ending in 2007 reflects a balance between the need to have more data for analysis and the need to ensure that information on government quality does not become stale. It also has the advantage of avoiding the possible structural break effects of the recent financial crisis on corporate cash holdings.

We exclude from the sample financial firms and firms that are not headquartered in any of the 120 cities covered by the World Bank survey, and the cities that do not have any listed companies. We focus on the place of incorporation because regional protection is reported to be common and strong in China, and a local government invariably discriminates against firms incorporated in other places in allocating scarce resources (Li et al., 2004). In addition, compared with other classification criteria, using the place of incorporation enables us to group firms in an unambiguous way. ${ }^{9}$

Our final sample consists of a maximum number of 3,074 firm-years across 114 cities from 2005 to 2007, and the exact number of observations may vary according to model specifications due to the missing values on some variables. Accounting and ownership variables are extracted from the China Stock Market and Accounting Research (CSMAR) database that is available from WRDS.

\subsection{Government quality measures}

We adopt the definition of good government used in La Porta et al. (1999) and Levine (2005): a good government protects property rights, keeps regulations and taxes light, is

\footnotetext{
${ }^{9}$ While it is rare, it is possible that a firm's major assets and financing are based outside the place of incorporation. The lack of data on the firms' geographical distribution of assets precludes us from matching a firm to a city according to its asset distribution. We acknowledge this is an unavoidable limitation in our study. We, however, note that this possibility should work against finding a negative relation between local government quality and the level of corporate cash holdings.
} 
clean, and provides efficient public services. Building upon this and taking into account data availability from our database and China's political practice, we construct the following four measures of government quality that are obtained from the World Bank Survey (2006). ${ }^{10}$

\subsubsection{Property rights protection}

Our first measure is a city-level index on property rights protection by the local government and local court. The index ranges from 0 to 1 , with a higher value indicating better property rights protection by law/contract enforcement. Cull and Xu (2005) also use a similar index in their study of property rights security on firm reinvestment in China.

\subsubsection{Government efficiency}

Similar to the "bureaucratic delays" of La Porta et al. (1999), we use the average number of days in a year that a firm needs to spend in interacting with government bureaucracies to measure the efficiency of government provision of public services. Chinese firms have to interact frequently with the government to obtain licenses or permission to conduct business or undertake projects. If government quality is low, firms may have to wait a long time for an outcome. Thus a financing process can be delayed, especially when the finance comes from state-owned banks, equity issuance that always needs the first-round approval of the local government ${ }^{11}$, or government subsidies. As a result, firms may face greater financial constraints and need to hold more cash to avoid passing up valuable investment opportunities. Alternatively, firms may spend extra resources to "speed up" the approval process when dealing with a low-quality government. The extra resources expended represent the rents extracted by politicians. To limit the potential loss due to government expropriation, firms may need to keep a low level of cash.

\footnotetext{
${ }^{10}$ These measures of government quality are also used in some prior studies. For example, Johnson et al. (2000) use taxation, corruption and confidence in court as measures to investigate why firms conduct unofficial activities. Fan et al. (2007) use property rights protection and corruption as measures of government quality in their examination of the impact of government quality on FDI inflow.

${ }^{11}$ An equity issuance needs the recommendation of a local government office, but is subject to the rigorous screening and final approval of the China Securities Regulatory Commission (CSRC) at the national level.
} 
This is because the amount of rents that government officials expect to extract from a firm depends upon the paying ability of the firm (Svensson, 2003).

\subsubsection{Tax burden}

Our third measure of government quality is taxes and fees that a firm pays as a percentage of its sales. This measure includes not only the taxes but also the various fees collected by the government. To be specific, the measure consists of value added tax, income tax, business, resource, land, and real estate taxes, plus miscellaneous administrative levies and charges. All the taxes and fees except for value added tax and part of income tax are directly collected by local governments. Taxation and fee collection is considered an important means of government expropriation (Cull and $\mathrm{Xu}, 2005$; Stulz, 2005). Therefore, a low-quality government can use this tool to extract firms' resources while a good government can use this instrument to foster a more conducive business environment for local firms.

\subsubsection{Corruption}

The fourth measure is firm's average expenditure on travel and entertainment (scaled by total sales of a firm) in a city. Managers of China's listed firms often use such expenditure as "informal payment" to bribe government officials. Cai et al. (2010) use the same variable as a measure of corruption in Chinese firms and find that such expenditure includes both "grease money" that helps firms obtain better government service, and "protection money" that helps firms reduce government expropriation by taxation.

To ease the interpretation of results, we multiply the last three measures by -1 so that for all four measures, a higher value indicates higher government quality. Since these four proxies measure different aspects of a good government, we also construct an aggregate government quality index following Francis et al. (2004). Specifically, we first rank each government quality proxy into decile groups. We then calculate the mean ranking of the

four proxies to form an aggregate government quality index. A higher value in the 
aggregate index indicates higher government quality. ${ }^{12}$

\subsection{Dependent variable and control variables}

Following Dittmar et al. (2003) and Harford et al. (2008), we use the logarithm of firms' cash ratio that is defined as the amount of cash and cash equivalents scaled by total assets net of cash and cash equivalents as our dependent variable. In addition to government quality proxies, we follow the literature on firms' cash holdings (e.g., Opler et al., 1999; Dittmar and Mahrt-Smith, 2007; Capiro et al., 2010) to include in our models some common control variables that have been shown to affect cash holdings.

Specifically, we control for several economic determinants of corporate cash holdings: the natural logarithm of total assets, net working capital (net of cash and equivalents)/net assets (NWC), firm leverage, Q, cash flow from operating activities (earnings before extraordinary items and depreciation minus cash dividends) divided by total assets, capital expenditure divided by total assets, and a dummy on dividend payout.

The main firm-level insider agency problem proxy we use is ownership wedge that is defined as the ultimate owner's control rights minus its cash flow rights. Using the separation of control rights and cash flow rights to proxy for the insider expropriation problem is a common practice when ownership structure is concentrated (e.g., Claessens et al., 2000; Fan et al., 2002). A similar proxy is also used in Lin et al. (2011) on ownership structure and financial constraints. The larger the ownership wedge, the higher the incentives for the controlling shareholder to expropriate minority shareholders. We expect firms with a large ownership wedge to keep more cash to facilitate rent extraction.

We also include firm identity (state-owned or not) in our models to control for the possibility that SOEs and private firms may have different patterns in cash holding

\footnotetext{
12 As a robustness check, we also use a principal component analysis to aggregate the four proxies and find consistent results. See the discussion in Section 5.3.
} 
decisions. ${ }^{13}$ Such differences may arise from the different access to finance and different agency problems between SOEs and private firms. Private firms have less access to finance than SOEs and so may need to hoard more cash to prepare for future adversity. In addition, private firms tend to have more effective monitoring over the management (Zou et al., 2008). If self-interested managers value the flexibility and discretion afforded by keeping more cash, private firms are expected to keep less cash because shareholder monitoring is more effective. On the other hand, if self-interested managers value more the private benefit from spending cash, more effective monitoring of managers in private firms may result in more cash. ${ }^{14}$ Therefore, the effect of firm identity on cash holdings is not clear cut ex ante.

Chinese firms, especially SOEs, may sometimes receive direct subsidies from local governments, which could increase or decrease cash holdings. We thus include government subsidies divided by total assets as an additional control variable.

One side of our argument on the effects of government quality on corporate cash holdings focuses on how a good government helps relieve firms' financial constraints and thereby enable them to hold less cash. If a good government helps cultivate a more developed local financial market, in particular a more sophisticated banking sector, local firms should have better access to finance and so hold less cash. While this possibility is not inconsistent with our hypothesis, we follow Dittmar et al (2003) and Kalcheva and Lins (2007) to control for financial market development (proxied by the ratio of bank loans to GDP) and economic development (GDP per capita) in our model to show that the effect of a good government on corporate cash holding goes beyond such a possibility. That is, we conjecture the main channels through which a good government helps mitigate financial constraints are: a good government enhances the credibility of local firms and lower the

\footnotetext{
13 The ownership identity data are obtained from China Center for Economic Research (CCER) database compiled by Peking University.

14 See Harford et al. (2008) for a detailed discussion of these different arguments.
} 
credit risk of banks and a firm's trading partners so that local firms can access more bank loans and trade credit financing.

Appendix 1 provides detailed definitions of all variables. Except for net working capital/net assets, all other control variables are calculated at the beginning of the year to mitigate the endogeneity problem and to ease the interpretation of results. Non-logged continuous variables are winsorized at $1 \%$ at both tails to mitigate the undue effects of extreme values.

\subsection{Summary statistics}

The descriptive statistics are presented in Table 1 . The cash ratio has a mean of 0.200 and a median of 0.138 , and both are higher than the figures reported in the cross-country sample used in Dittmar et al. (2003) and Kalcheva and Lins (2007). This is consistent with our previous argument that cash holding decisions are important for Chinese companies that often face financial constraints. In addition, our sample firms have a mean total debt ratio of $54.2 \%$, a mean Q of 1.179 , and a mean chance of paying a cash dividend of about $50 \%$.

The government quality measures also show reasonable variance across different cities. In unreported results, we undertake a reliability test for the consistency of our four government quality measures. The test shows a scale reliability coefficient of 0.86 that is well above the rule-of-thumb reliability threshold, indicating that the four variables are internally consistent. Also unreported correlation coefficients suggest that the cash ratio is negatively related to proxies of government quality, which provides preliminary support for our financial constraint mitigation hypothesis rather than the government expropriation argument.

[Insert Table 1 here] 


\section{Empirical results}

\subsection{Government quality and cash holdings}

We first report the firm-level results from regressing the logged cash ratio on government quality measures in Table 2 . We include one government quality proxy at a time. The results show that all the government quality proxies and their aggregate are loaded negatively and significantly. Therefore, firms hold less cash when government quality is higher. This finding is consistent with the argument that a good government helps relieve local firms' financial constraints and thereby enable them to hold less cash. Note that our models have included explicit controls for the level of economic and debt market development, therefore the negative relation between government quality and corporate cash holdings is not an artifact of the coincidence of a good government and better economic and financial market development. ${ }^{15}$ The effect of government quality on cash holdings also appears economically significant, for example, when the property rights protection index increases by one standard deviation, a firm's cash holding lowers by about $2 \%$.

Regarding the control variables, consistent with Dittmar et al. (2003), we find firms with more growth opportunities (as measured by a higher Q value) and/or more operational cash flow tend to hold more cash. As in Kalcheva and Lins (2007) and Capiro et al. (2010), firms with more working capital, higher leverage and capital expenditure tend to hold less cash. Also we find that firms paying dividends in the previous year hold more cash in the current period probably because they want to keep sufficient cash to maintain the "sticky" dividend payment.

In addition, we find that private firms have more cash holdings than SOEs. This is consistent with the notion that private firms have limited access to finance and need to hoard more cash to prepare for future adversity than SOEs. Alternatively, it may reflect that

\footnotetext{
15 Private credit/GDP does not enter the model significantly. Kusnadi and Wei (2011) also find that once legal protection of investors is controlled for, financial development has no incremental impact on firms' cash management policies.
} 
the more effective monitoring of managers in private firms reduces managers' waste of cash in overinvestments. Other control variables do not have a significant effect on cash holdings.

[Insert Table 2 here]

Since each city has a different number of firms in our sample, a concern is whether the above results are driven by a few cities with a large number of firms. To mitigate this concern, we follow Caprio et al. (2010) to run a city-level regression in which firm-level controls are averaged across all sample firms in a city in a year. The results, presented in Table 3, are similar to those obtained from the firm-level analysis reported in Table 2: government quality is negatively related to cash holdings.

[Insert Table 3 here]

\subsection{Evidence on good governments relieving financial constraints}

Although a negative relation between government quality and corporate cash holdings is consistent with our financial constraint mitigation hypothesis, more direct evidence will lend stronger support for the argument. For this purpose, we employ the following investment-cash sensitivity model from Fazzari et al. (1988): ${ }^{16}$

Investment $=f\left(C F\right.$, Government quality, $C F^{*}$ Government quality, lagged $Q$, Controls $)$

Where Investment is defined as capital expenditure/year-beginning total assets, $C F$ is cash flow (i.e., earnings before extraordinary items and depreciation minus

16 This model setup is also used in McLean et al. (2011) on the investment sensitivity to cash flow and Q. 
dividends/year-beginning total assets), and $Q$ for investment opportunity.

Fazzari et al. (1988) argue that since external financing is more costly than internal financing, firms rely more on internal financing when they face serious financial constraints. As a result, most capital expenditure should be financed by internally generated cash flow. Therefore, the coefficient of $C F$ is expected to be significantly positive and its value can be regarded as a measure of the degree of financial constraint.

We introduce a government quality measure into the model and interact it with cash flow. If a good government does help relieve financial constraints, the coefficient for $C F^{*}$ Government quality is expected to be significantly negative. ${ }^{17}$ The results reported in Table 4 confirm our financial constraint mitigation hypothesis. In all the five government quality proxies, the coefficient of the interaction term is negatively significant, indicating that a good government does help reduce financial constraints, and thus reduce cash holdings in local firms.

[Insert Table 4 here]

We also conduct city-level analyses on the role of government quality in reducing financial constraints. Following McLean et al. (2011), we first regress capital expenditure/year-beginning total assets on cash flow from operations/year-beginning total assets $(C F)$ and lagged $Q$ using all sample firms within a city to obtain the coefficient of $C F$ (i.e., the sensitivity of investment to cash flow in a city). ${ }^{18}$ We then regress $\operatorname{Ln}(1+$ coefficient of $C F$ ) on government quality measures controlling for GDP per capita and some firm characteristics averaged across the sample firms within a city. The regression coefficients of government quality measures can then be interpreted to be the marginal

\footnotetext{
17 To mitigate collinearity, we de-mean both $C F$ and government quality measures and use them in regression and in constructing the interaction term.

18 When we estimate $C F$ coefficients for each city, we require each city to have at least ten usable firm-years and only 88 cities meet this requirement.
} 
impacts of government quality on the financial constraints measured as the sensitivity of investment to cash flow.

The results from the second stage regressions as reported in Table 5 show that all local government quality measures are significantly and negatively related to financial constraint, suggesting that a good government does help reduce firms' financial constraints.

[Inset Table 5 here]

However, whether investment-cash flow sensitivity is a good indicator of financial constraint is not without controversy in the literature (e.g., Kaplan and Zingales, 1997, 2000). We thus use an alternative measure of financial constraints, i.e., cash flow sensitivity of cash posited in Almeida et al. (2004). The intuition of this measure is that if firms are more financially constrained, they tend to save more cash flow as cash to prepare for future adversity. To be specific, we employ the following model:

\section{$\Delta$ Cash ratio $=f($ Cash flow, Government quality, Cash flow*Government quality, Controls)

Following Almeida et al. (2004), the controls in Equation 2 include firm size, Q, investment, change in non-cash net working capital $(\triangle \mathrm{NWC})$, and change in short-term debt. Appendix 1 provides detailed definition of these variables. We expect the coefficient for the interaction term between cash flow and government quality to be significantly negative. This is indeed what we find in Table 6. Therefore, we find direct evidence that government quality helps relieve the financial constraints facing local firms. Otherwise, the results on the control variables are consistent with those in Almedia et al. (2004).

[Insert Table 6 here] 


\subsection{The channels through which a good government relieves financial constraints}

Thus far, we have found that higher government quality leads to a lower level of corporate cash holdings and the result is due to good governments helping relieve the financial constraints that local firms face. A natural follow-up question is through what channels a good government does this.

We consider three possibilities. First, as we have discussed in the introduction part, Chinese firms rely heavily on bank debt financing. Since a good government protects property rights by enforcing law/business contracts, the chance for banks to secure loan repayments and to repossess collateral in the event of a default will be higher. Banks are therefore more willing to lend to companies in cities where government quality is higher and this increases firms' access to bank loans. Second, a good government provides better legal and administrative systems, which improves trust among business entities and enhances contract enforcement. As a result, it is possible for firms to use more trade credit such as accounts payable as a source of short-term finance (Liu et al., 2009).

We test these arguments by regressing firms' access to bank loans (proxied by the sum of short-term and long-term loans that the company borrows from banks scaled by total assets) and firms' accounts payable divided by total net assets on government quality. We focus on the aggregate government quality measure and the results shown in Panel A of Table 7 suggest that government quality is positively related to firms' access to bank loans and accounts payable, indicating that a good government indeed facilitates bank and trade credit financing for firms.

[Insert Table 7 here] 
A third channel that we consider is foreign direct investment (FDI). As a result of China's open-door policy, foreign investment has become an important capital source for firms and China has long been one of the largest recipients of FDI in the world (Fan, Morck, $\mathrm{Xu}$ and Yeung, 2007). Taking advantage of this institutional feature, we test whether a better government attracts more FDI. Our FDI data (both realized and contracted FDI) are obtained from China City Statistical Yearbook 2005-2007. ${ }^{19}$ We regress the natural logarithm of contracted FDI and realized FDI (in 10,000 US dollars) at the city level controlling for GDP growth, city road length, population, education expenditure per capita, and unemployment rate. The results in Panel B of Table 7 show that there is a positive association between the aggregate government quality measure and FDI. In unreported analysis, we have also empirically verified that the three channel variables (i.e., a firm's bank loan ratio, accounts payable/total net assets, and the FDI attracted) are negatively related to firms' cash ratio that is the dependent variable.

Taking the above results together, we conclude that a good government relieves firms' financial constraints, which reduces corporate cash holdings. We note that this only speaks of the dominating effect of a good government perceived by corporate insiders and we cannot rule out the possibility of government expropriation that might coexist and exert an opposite influence on firms' cash holding decisions.

\subsection{Differential impacts of government quality on cash holdings in firms with different ultimate owners}

Government quality may have differential effects on firms with different ultimate owners. As discussed earlier, compared with SOEs, private firms are often disadvantaged in transition economies including China. For example, they have less access to external formal finance (Allen et al., 2005; Firth et al., 2008; 2009), are subject to more unfavorable government regulations, or pay more "extralegal" fees (Johnson et al., 2000; McMillan and

${ }^{19}$ FDI data for some city-years are not available. 
Woodruff, 2002). As private firms face more financial constraints and are more eager to access external financing, the marginal benefits of a good government in mitigating financial constraints should be greater for private firms. That is, cash holdings of private firms are more sensitive to government quality than those of SOEs.

The above argument is examined in Table 8 . We first create an interaction term between the Private dummy (which equals one if the ultimate owner is not a state-owned entity and zero otherwise) and government quality. We expect the coefficient of the interaction term to be negatively significant. The results reported in Table 8 generally support the argument that the financial constraint mitigation effect of a good government is more beneficial to private firms than to SOEs.

[Insert Table 8 here]

\subsection{Endogeneity}

Despite the fact that our dependent variable is at the firm level and government quality is at the city level, endogeniety might be a source of concern. Specifically, our government quality measures are constructed at the city level based on the average of firms' perceptions of certain issues, and so they are potentially subject to the possibility of reverse causality. Note that our previous interactive analysis on the differential effects of government quality on cash holdings in firms with different identities of ultimate owners can to some extent help mitigate this concern. This is because any reverse causality must explain not only the observed negative relation between government quality and companies' cash ratio, but also the observed cross-sectional difference. Nevertheless, in this section we employ a formal instrument variable (IV) estimation to further mitigate the endogeneity concern.

We include three variables from the World Bank report concerning each city's progress towards a harmonious society: green space per capita, infant mortality, and days 
with good or excellent air quality. These variables to a large extent indicate the amount of effort made by local governments to improve social welfare and as a result, they are expected to be positively related to government quality. Clearly, the variables have no direct relation with corporate cash holdings unless through government quality or economic development that is already accounted for by our model. Therefore, we use the three variables as our instrument variables. Since we have four government quality proxies and each of them may capture only one aspect of the role of government, we focus on the aggregate government quality measure in the instrumental variable estimation for brevity.

We undertake a two-stage least square regression analysis. In the first stage, we regress government quality on the above instruments and other control variables in the cash holding model to obtain predicted government quality. The results from the first stage regression are shown in Column (1) of Table 9. The three IVs have positive and significant coefficients. The $F$-tests of the three IVs as the excluded instruments are always highly

significant ( $p$-values lower than 0.01). We also calculate Shea's (1997) partial $R^{2}$ from the first-stage regressions. The values of $R^{2}$ all well exceed the suggested ("rule of thumb") hurdle of $10 \%$. The Hansen's J-test of the over-identification has a $p$-value $=0.489$ and so we cannot reject the null hypothesis that the three excluded instruments are exogenous. These tests suggest that our instruments are valid in explaining the variation of the potentially endogenous government quality. In the second stage, we regress cash holdings on the predicted government quality measures, and the results reported in Column (2) of Table 9 remain consistent with our prior findings.

[Insert Table 9 here]

\subsection{The interaction between state agency problem and the insider agency problem}

As discussed earlier, a good government may also indirectly affect corporate cash 
holdings through its interaction with the insider agency problem. We hypothesize in the introduction part that a large ownership wedge is expected to lead the company to keep more cash to facilitate extraction and government quality attenuates the positive relation between ownership wedge and corporate cash holdings. We examine these possibilities in this section. The results are reported in Table 10.

[Insert Table 10 here]

In Column (1), we first omit government quality to see how the insider agency problem alone affects corporate cash holdings. Ownership wedge has a positive and statistically significant coefficient, suggesting that insiders (controlling shareholders and management under their control) let firms hold more cash to facilitate the conversion of firms' assets into private benefits. The result broadly corroborates the finding of Kalcheva and Lins (2007) that use international data and measure the insider agency problem by managerial control rights.

In Column (2), we add back the aggregate government quality proxy. Consistent with our earlier analysis, the coefficient of the government quality proxy is still negative and statistically significant. Also consistent with our results from Table 2, the coefficient of ownership wedge becomes insignificant.

In Column (3), we define a dummy for high aggregate government quality (AGQ) that equals one if AGQ is above the sample median, and interact it with ownership wedge. The high AGQ dummy has a negative coefficient and the interaction term is also loaded negatively. This suggests that the effect of government quality on corporate cash holdings is strictly negative, supporting the financial constraint mitigation argument. The negative and significant coefficient on the interaction term indicates that a good government attenuates the positive relation between ownership wedge and cash holdings because it 
increases the cost to corporate insiders of extracting private benefits (e.g., cash) from the firms they control. It is also consistent with Stulz's (2005) argument that state expropriation and insiders' expropriation of private benefits often reinforce each other.

The coefficient of ownership wedge is positive and significant. Therefore, in cities with a lower-than-sample-median government quality index, a large ownership wedge is associated with more corporate cash holdings. In contrast, in cities with a higher-than-sample-median government quality index, ownership wedge has a coefficient of $-0.252(=0.521-0.773)$, and a Wald test suggests that it is not statistically significant. Therefore, the insider agency problem is more pronounced when government quality is low. Overall, we conclude that the quality of external institutions such as the government appears to have a first-order effect on corporate cash holdings.

\section{Robustness checks}

We conduct various robustness checks in this section.

\subsection{Alternative data years}

Since cash ratio (the dependent variable) is measured over the period 2005-2007 while government quality (the key explanatory variable) is taken from the World Bank survey that reflects the situation in 2004 , one may wonder how sensitive our results are to the choice of the measurement years. In unreported results, we run a regression using the cash ratio and other independent variables for year 2005 only and another regression using the cash ratio and other independent variables averaged over year 2005-2007. Our key finding is not altered qualitatively by either of the alternatives.

\subsection{An alternative aggregate measure of government quality}

Thus far, we have aggregated the four government measures by calculating the mean decile ranking of each measure. As a robustness check, we construct the aggregate measure 
of government quality by a principal component analysis and regress cash holdings on this aggregate measure. The untabulated results show that this variable also has a significant and negative relation with cash holdings.

\section{Conclusion}

We investigate the role of government quality in firms' cash holding decisions in China's institutional setting with a unique dataset from the World Bank covering 120 Chinese cities. Using single-country data enables us to have a cleaner test of the effects of law enforcement on cash holdings by effectively holding shareholder rights conferred by law on paper constant.

We hypothesize that on the one hand, a good government refrains from expropriating firms and enables firms to hold more cash. On the other hand, a good government may help relieve financial constraints and enable firms to hold less cash - a new channel that has been neglected by the prior literature. A good government may also indirectly affect corporate cash holdings through its effect on the insider agency problem. We find that local government quality has a negative effect on corporate cash holdings, which suggests that the financial constraint mitigation argument dominates the expropriation argument in firms' cash holding decisions in China. We also find that a large ownership wedge is associated with more corporate cash holdings to facilitate extraction when government quality is low. These findings are broadly consistent with Stulz's (2005) argument on the interaction between the state agency problem and the insider agency problem in affecting corporate policies.

Specifically, our results show that a good government reduces firms' financial constraints by facilitating firms' access to bank loans and trade credits and by attracting more FDI into the region. We also find that cash holdings by private firms are more sensitive to local government quality than SOEs. These results further bolster our key 
finding that a good local government mitigates the financial constraints of local firms and enable them to hold less cash.

The dominance of the financial constraint mitigation argument over the expropriation argument regarding the roles of local governments is understandable in China because improving economic performance has become a key task of local governments under the state policy of "concentrating on economic development" since the reform on decentralizing administrative rights in the 1980s (Expert Group, 1995).

Our study represents a refined test of the effects of the enforcement-component of investor protection and firm-level governance on corporate cash holdings, thereby adding to the cash holding literature that contains mixed evidence regarding the effects of investor protection on cash holdings. It also contributes to the limited research on how state policies interact with managerial incentives to shape firm policies. Future studies should test the financial constraint mitigation argument using the US or international data. 


\section{References}

Allen, F., Qian, J., Qian, M.J., 2005. Law, finance, and economic growth in China. Journal of Financial Economics 77, 57-116.

Allen, F., Chakrabarti, R., De, S., Qian, J., Qian, M.J., 2007. Financing firms in India, Working Paper 06-08, Wharton Financial Institutions Center, University of Pennsylvania.

Almeida, H., Campello, M., Weisbach, M. S., 2004. The cash flow sensitivity of cash. The Journal of Finance 59, 1777-1804.

Ayyagari, M., Demirguc-Kunt, A., Maksimovic, V., 2010. Formal versus informal finance: Evidence from China. Review of Financial Studies 23, 3048-3097.

Bates, T.N., Kahle, K.M., Stulz, R.M., 2009. Why do U.S. firms hold so much more cash than they used to? Journal of Finance 64, 1985-2021.

Cai, H., Fang, H., Xu, C.L., 2011. Eat, drink, firms and government: an investigation of corruption from entertainment and travel costs of Chinese firms. Journal of Law and Economics 54, 55-78.

Caprio, L., Faccio, M., McConnell, M., 2010. Sheltering corporate assets from political extraction. Working paper, Purdue University.

Claessens, S., Djankov, S., Lang, L.H.P., 2000. The separation of ownership and control in East Asian corporations. Journal of Financial Economics 58, 81-112.

Cull, R., Xu, L.C., 2005. Institutions, ownership, and finance: the determinants of profit reinvestment among Chinese firms. Journal of Financial Economics 77, 117-146

Desai, M., Dyck, A., Zingales, L., 2007. Theft and taxes. Journal of Financial Economics $84,591-623$.

Dittmar, A., Mahrt-Smith, J., 2007. Corporate governance and the value of cash holdings. Journal of Financial Economics 83, 599-634.

Dittmar, A., Mahrt-Smith, J., Servaes, H., 2003. International corporate governance and corporate cash holdings. Journal of Financial and Quantitative Analysis 38, $111-133$.

Durnev, A., Fauver, L., 2010. Stealing from thieves: Firm governance and performance when states are predatory. Working paper, McGill University.

Expert Group, 1995. Report on reform and development in China - The Chinese road. Chinese Finance and Economic Press, Beijing.

Fan, J.P.H., Morck, R., Xu, L.C., Yeung B., 2007. Does 'good government' draw foreign capital? Explaining China's exceptional foreign direct investment inflow. World Bank Policy Research Working Paper No. 4206.

Fan, J.P.H, Wei, K.C.J., Xu, X., 2011. Corporate finance and governance in emerging markets: A selective review and an agenda for future research. Journal of Corporate Finance 17, 207-214

Fan, J.P.H., Wong, T.J., 2002. Corporate ownership structure and the informativeness of accounting earnings in East Asia. Journal of Accounting and Economics 33, 401-425.

Fan, J.P.H., Wong, T.J., Zhang, T., 2007. Politically connected CEOs, corporate governance, and Post-IPO performance of China's newly partially privatized firms. Journal of Financial Economics 84, 330-357.

Faulkender, M., Wang, R., 2006. Corporate financial policy and the value of cash. Journal 
of Finance 61, 1957-1990.

Fazzari, S.M., Hubbard, R.G., Petersen, B.C., 1988. Financial constraints and corporate investment. Brooking Papers on Economic Activity (1), 141-206.

Firth, M., Lin, C., Liu, P., Wong, S., 2009. Inside the black box: Bank credit allocation in China's private sector. Journal of Banking \& Finance 33, 1144-1155.

Firth, M., Lin, C., Wong, S., 2008. Leverage and investment under a state-owned bank lending environment: Evidence from China. Journal of Corporate Finance 14, 642-653.

Francis, J., LaFond, R., Olsson, P.M., Schipper, K., 2004. Costs of equity and earnings attributes. The Accounting Review 79, 967-1010.

Frye, T., Shleifer, A., 1997. The invisible hand and the grabbing hand. American Economic Review 87, 354-358.

Harford, J., 1999. Corporate cash reserves and acquisitions. Journal of Finance 54,1969-1997.

Harford, J., Mansi, S., Maxwell, W., 2008. Corporate governance and firm cash holdings in the US. Journal of Financial Economics 87, 535-555.

Jensen, M.C, 1986. Agency costs of free cash flow, corporate finance, and takeovers. American Economic Review 76, 323-329.

Johnson, S., Kaufmann, D., McMillan, J., Woodruff, C., 2000. Why do firms hide? Bribes and unofficial activity after communism. Journal of Public Economics 76, 495-520.

Kalcheva, I., Lins, K.V., 2007. International evidence on cash holdings and expected managerial agency problems. Review of Financial Studies 20, 1087-1112.

Kaplan, S., Zingales, L., 1997. Do investment-cash flow sensitivities provide useful measures of financing constraints? Quarterly Journal of Economics 112, 169-215.

Kaplan, S., Zingales, L., 2000. Investment-cash flow sensitivities are not valid measures of financing constraints. Quarterly Journal of Economics 115, 707-712.

Kusnadi, Y., Wei, K.C.J., 2011. The determinants of corporate cash management policies: evidence from around the world. Journal of Corporate Finance 17, 725-740.

La Porta, R., Lopez-de-Silanes, F., Schleifer, A., Vishny, R., 1999. The quality of government. Journal of Law, Economics and Organizations 15, 222-279.

Levine, R., 2005. Law, endowments, and property rights, Journal of Economic Perspectives 19, 61-88.

Li, S., Hou, Y.Z., Liu, Y.Z., Chen, B., 2004. Regional protection in China: Survey and analysis. Economic Research Journal, Issue 11, 78-95.

Lin, C., Lin, P., Song, F., 2010. Property rights protection and corporate R\&D: Evidence from China. Journal of Development Economics 93, 49-62.

Lin, C., Ma, Y., Xuan, Y., 2011. Ownership structure and financial constraints: Evidence from a structural estimation. Journal of Financial Economics, forthcoming.

Liu F., Li, L., Xue, Y., 2009. Trust, transaction cost and mode of trade credit. Economic Research Journal, Issue 8, 60-72.

McLean, R. D., Zhang, T., Zhao, M., 2011. Why does the law matter? Investor protection and its effects on investment, finance, and growth. Journal of Finance, Forthcoming.

McMillan, J., Woodruff, C., 2002. The central role of entrepreneurs in transition economies. Journal of Economic Perspectives 16, 153-170. 
Myers, S.C., and Rajan, R.G., 1998, The paradox of liquidity, The Quarterly Journal of Economic, 113, 733-771.

Opler, T., Pinkowitz, L., Stulz, R., Williamson, R., 1999. The determinants and implications of corporate cash holdings. Journal of Financial Economics 52, 3-46.

Pinkowitz, L., Stulz, R., Williamson, R., 2006. Does the contribution of corporate cash holdings and dividends to firm value depend on governance? A cross-country analysis. Journal of Finance 61, 2725-2751.

Qian, Y., Roland, G., 1998. Federalism and the soft budget constraint. The American Economic Review 88, 1143-1162.

Svensson, J., 2003. Who must pay bribes and how much? Evidence from a cross-section of firms. Quarterly Journal of Economics 118, 207-230.

Shea, J., 1997. Instrument relevance in multivariate linear models: A simple measure. Review of Economics and Statistics 79, 348-352.

Shleifer, A., Vishny, R.W., 1998. The grabbing hand: Government pathologies and their cures. Harvard University Press.

Stulz, R., 2005. The limits of financial globalization. The Journal of Finance 60, $1595-1938$.

World Bank, 2006. Governance, Investment Climate, and Harmonious Society Competitiveness Enhancements for 120 Cities in China. Survey report.

Xiao, Z., Zou, H., 2008. The determinants of capital structure and equity financing preference in listed Chinese companies. Economic Research Journal, Issue 6, 119-134.

Zou, H., Adams, M.B., 2008. Debt capacity, cost of debt, and corporate insurance. Journal of Financial and Quantitative Analysis 43, 433-466.

Zou, H., Wong, S., Shum, C., Xiong, J., and Yan, J., 2008. Controlling-minority shareholder incentive conflicts and directors' and officers' liability insurance: Evidence from China. Journal of Banking \& Finance 32, 2632-2645. 


\section{Appendix 1}

\section{Variable Definition}

\begin{tabular}{|c|c|}
\hline Variables & Definition \\
\hline \multicolumn{2}{|l|}{ Proxies for government quality } \\
\hline Property rights protection & $\begin{array}{l}\text { The city-level index (ranges between } 0 \text { and 1) measures the likelihood that the } \\
\text { responding firms' property and contract rights would be protected and enforced } \\
\text { in business disputes in } 2004 \text { (Source: the World Bank Survey 2006) }\end{array}$ \\
\hline Government efficiency & $\begin{array}{l}\text { Average number of days in a year that an entrepreneur interacts with } \\
\text { government bureaucrats in 2004, and the measure is multiplied by }-1 \text { (Source: } \\
\text { the World Bank Survey 2006) }\end{array}$ \\
\hline Lightness of tax burden & $\begin{array}{l}\text { Taxation and miscellaneous administrative fees as percentage of sales in 2004, } \\
\text { and the measure is multiplied by }-1 \text { (Source: the World Bank Survey 2006) }\end{array}$ \\
\hline Government cleanliness & $\begin{array}{l}\text { Average travel and entertainment costs relative to sales in 2004, and the } \\
\text { measure is multiplied by }-1 \text { (Source: the World Bank Survey 2006) }\end{array}$ \\
\hline $\begin{array}{l}\text { Aggregate government quality } \\
\text { Firm-level financial characteri }\end{array}$ & $\begin{array}{l}\text { Mean decile ranking of the above four government quality measures } \\
\text { ics }\end{array}$ \\
\hline Cash ratio & $\begin{array}{l}\text { The ratio of cash and cash equivalents to net assets, where net assets = total } \\
\text { assets - cash and cash equivalents }\end{array}$ \\
\hline Cash flow & $\begin{array}{l}\text { Earnings before extraordinary items and depreciation minus cash dividends, } \\
\text { scaled by total assets }\end{array}$ \\
\hline Q & $\begin{array}{l}\text { The sum of the market value of equity and book value of total liabilities divided } \\
\text { by book value of total assets. The market value of tradable shares is calculated } \\
\text { based on the year-end share price; price of non-tradable shares is set to be the } \\
\text { per-share book value of equity }\end{array}$ \\
\hline Firm size & Natural logarithm of book value of total assets \\
\hline Leverage & Total debt divided by total assets \\
\hline Short-term debt & The ratio of short-term debt to total assets \\
\hline Bank loan & $\begin{array}{l}\text { The sum of all short-term and long-term loans that the company borrows from } \\
\text { banks, scaled by total assets }\end{array}$ \\
\hline Accounts payable & The ratio of accounts payable to net assets \\
\hline NWC & (Net working capital - cash and cash equivalents)/net assets \\
\hline Capex & Capital expenditure/total assets \\
\hline Dividend payout $(0 / 1)$ & $\begin{array}{l}\text { A dummy that equals one if a firm paid a cash dividend in a year and zero } \\
\text { otherwise }\end{array}$ \\
\hline Subsidy & Subsidies provided by governments to firms scaled by total assets. \\
\hline
\end{tabular}

Private $(0 / 1)$

A dummy variable that equals to one if the ultimate controlling shareholder is not a state-owned entity and zero otherwise. 
Ownership wedge

City-level characteristics

Realized FDI

Contacted FDI

Private credit/GDP

GDP per capita

GDP growth

Road

Population

Education expenditure

Unemployment
Control rights of the ultimate owner - cash flow rights of the ultimate owner $\mathrm{Ln}$ (the total amount of FDI received by a city (in 10,000 US dollars))

$\mathrm{Ln}$ (the total amount of contracted FDI by a city (in 10,000 US dollars))

Bank loans/GDP in the province in which the firm is located

GDP per capita

A city's $\mathrm{GDP}_{\mathrm{t}} / \mathrm{GDP}_{\mathrm{t}-1}-1$

A city's road length/the city's geographical size

Ln(a city's population (in millions))

A city's education expenditure per capita (in yuan)

A city's unemployment rate (\%)

(Note: All non-logged continuous variables are winsorized at $1 \%$ at both tails). 
Table 1

Descriptive statistics

This table reports summary statistics of the main variables defined in Appendix 1 and used in subsequent analyses. City-level government quality proxies are for the 114 cities that meet our sample selection criteria (see Section 2.1). These proxies are taken from the World Bank Survey (2006). Except for firms' ultimate owner identity that is from the CCER database, firm characteristics are for the pooled firm-years for the 114 cities and are extracted from the CSMAR database.

\begin{tabular}{|c|c|c|c|c|c|c|}
\hline Variable & $\mathrm{N}$ & Mean & Std. Dev & $\mathrm{P} 25$ & P50 & P75 \\
\hline \multirow{2}{*}{\multicolumn{7}{|c|}{$\begin{array}{l}\text { City-level government quality } \\
\text { proxies }\end{array}$}} \\
\hline & & & & & & \\
\hline Property rights protection & 114 & 0.634 & 0.165 & 0.498 & 0.661 & 0.753 \\
\hline Government efficiency & 114 & 0.605 & 0.216 & 0.457 & 0.597 & 0.744 \\
\hline Lightness of tax burden & 114 & 4.945 & 1.390 & 4.000 & 5.000 & 5.800 \\
\hline Government cleanliness & 114 & 0.124 & 0.050 & 0.080 & 0.120 & 0.160 \\
\hline Aggregate government quality & 114 & 4.488 & 1.613 & 3.188 & 4.710 & 5.732 \\
\hline \multicolumn{7}{|l|}{ Firm characteristics } \\
\hline Cash ratio & 3073 & 0.200 & 0.221 & 0.070 & 0.138 & 0.245 \\
\hline NWC & 3073 & -0.118 & 0.330 & -0.247 & -0.087 & 0.068 \\
\hline Firm size & 3074 & 21.250 & 1.064 & 20.550 & 21.160 & 21.900 \\
\hline Leverage & 3074 & 0.542 & 0.315 & 0.379 & 0.524 & 0.641 \\
\hline $\mathrm{Q}$ & 3074 & 1.179 & 0.466 & 0.965 & 1.069 & 1.230 \\
\hline Capex & 3061 & 0.065 & 0.074 & 0.017 & 0.043 & 0.082 \\
\hline Cash flow & 3072 & 0.032 & 0.114 & 0.024 & 0.046 & 0.076 \\
\hline Dividend payout (0/1) & 3074 & 0.503 & 0.500 & 0.000 & 1.000 & 1.000 \\
\hline Short-term debt & 3072 & 0.883 & 0.159 & 0.831 & 0.952 & 0.998 \\
\hline Ownership wedge & 3001 & 0.092 & 0.120 & 0.000 & 0.000 & 0.179 \\
\hline Bank loan & 3074 & 18.560 & 5.438 & 18.840 & 19.950 & 20.960 \\
\hline Accounts payable & 3074 & 0.111 & 0.094 & 0.044 & 0.085 & 0.149 \\
\hline Subsidy & 3074 & 0.002 & 0.005 & 0.000 & 0.000 & 0.002 \\
\hline Private $(0 / 1)$ & 3074 & 0.328 & 0.470 & 0.000 & 0.000 & 1.000 \\
\hline \multicolumn{7}{|l|}{ Other control variables } \\
\hline Private credit/GDP & 3074 & 1.443 & 0.381 & 1.206 & 1.408 & 1.670 \\
\hline GDP per capita & 3074 & 9.731 & 0.656 & 9.170 & 9.737 & 10.110 \\
\hline
\end{tabular}




\section{Table 2}

\section{Corporate cash holdings and government quality: Firm-level regressions}

The table reports results from regressing logged cash ratio on government quality at the firm level. The other variables are defined in Appendix 1. Standard errors (clustered at the firm level) that are robust to both cross-sectional heteroskedasticity and within-firm serial correlation are used in computing $p$-value (in parentheses). ${ }^{*}, * *, * * *$ : statistically significantly different from zero at the $0.10,0.05$ and 0.01 level (two-tailed), respectively. The coefficients of the constant, year and industry dummies are omitted for brevity.

\begin{tabular}{|c|c|c|c|c|c|}
\hline $\mathrm{Y}=\mathrm{Ln}($ cash ratio $)$ & 1 & 2 & 3 & 4 & 5 \\
\hline Property rights protection & $\begin{array}{c}-0.116^{* * *} \\
(0.000)\end{array}$ & & & & \\
\hline Government efficiency & & $\begin{array}{c}-0.366^{* * *} \\
(0.002)\end{array}$ & & & \\
\hline Lightness of tax burden & & & $\begin{array}{c}-0.724 * * * \\
(0.000)\end{array}$ & & \\
\hline Travel and entertainment cost & & & & $\begin{array}{c}-0.147 * * * \\
(0.002)\end{array}$ & \\
\hline Aggregate government quality & & & & & $\begin{array}{c}-0.107 * * * \\
(0.000)\end{array}$ \\
\hline NWC & $\begin{array}{c}-0.531^{* * *} \\
(0.000)\end{array}$ & $\begin{array}{c}-0.522 * * * \\
(0.000)\end{array}$ & $\begin{array}{c}-0.534 * * * \\
(0.000)\end{array}$ & $\begin{array}{c}-0.541^{* * *} \\
(0.000)\end{array}$ & $\begin{array}{c}-0.535^{* * *} \\
(0.000)\end{array}$ \\
\hline Firm size & $\begin{array}{l}-0.002 \\
(0.945)\end{array}$ & $\begin{array}{l}-0.000 \\
(0.997)\end{array}$ & $\begin{array}{l}-0.000 \\
(0.989)\end{array}$ & $\begin{array}{c}0.001 \\
(0.976)\end{array}$ & $\begin{array}{l}-0.005 \\
(0.879)\end{array}$ \\
\hline Leverage & $\begin{array}{c}-1.198^{* * *} \\
(0.000)\end{array}$ & $\begin{array}{c}-1.247^{* * *} \\
(0.000)\end{array}$ & $\begin{array}{c}-1.240 * * * \\
(0.000)\end{array}$ & $\begin{array}{c}-1.235^{* * *} \\
(0.000)\end{array}$ & $\begin{array}{c}-1.217^{* * *} \\
(0.000)\end{array}$ \\
\hline Q & $\begin{array}{c}0.226^{* * *} \\
(0.000)\end{array}$ & $\begin{array}{c}0.227^{* * *} \\
(0.000)\end{array}$ & $\begin{array}{c}0.242 * * * \\
(0.000)\end{array}$ & $\begin{array}{c}0.237 * * * \\
(0.000)\end{array}$ & $\begin{array}{c}0.228^{* * *} \\
(0.000)\end{array}$ \\
\hline Capex & $\begin{array}{c}-0.694 * * \\
(0.013)\end{array}$ & $\begin{array}{c}-0.701 * * \\
(0.013)\end{array}$ & $\begin{array}{c}-0.674 * * \\
(0.018)\end{array}$ & $\begin{array}{l}-0.677 * * \\
(0.0172)\end{array}$ & $\begin{array}{c}-0.669 * * \\
(0.018)\end{array}$ \\
\hline Cash flow & $\begin{array}{c}1.315^{* * *} \\
(0.000)\end{array}$ & $\begin{array}{c}1.245^{* * *} \\
(0.000)\end{array}$ & $\begin{array}{c}1.260 * * * \\
(0.000)\end{array}$ & $\begin{array}{c}1.286^{* * * *} \\
(0.000)\end{array}$ & $\begin{array}{c}1.301 * * * \\
(0.000)\end{array}$ \\
\hline Dividend payout (0/1) & $\begin{array}{c}0.365^{* * *} \\
(0.000)\end{array}$ & $\begin{array}{c}0.338^{* * *} \\
(0.000)\end{array}$ & $\begin{array}{c}0.346^{* * *} \\
(0.000)\end{array}$ & $\begin{array}{c}0.349 * * * \\
(0.000)\end{array}$ & $\begin{array}{c}0.352 * * * \\
(0.000)\end{array}$ \\
\hline Subsidy & $\begin{array}{c}1.785 \\
(0.720)\end{array}$ & $\begin{array}{c}2.896 \\
(0.563)\end{array}$ & $\begin{array}{c}2.596 \\
(0.613)\end{array}$ & $\begin{array}{c}2.016 \\
(0.695)\end{array}$ & $\begin{array}{c}2.781 \\
(0.574)\end{array}$ \\
\hline Ownership wedge & $\begin{array}{c}0.169 \\
(0.431)\end{array}$ & $\begin{array}{c}0.295 \\
(0.168)\end{array}$ & $\begin{array}{c}0.319 \\
(0.136)\end{array}$ & $\begin{array}{c}0.324 \\
(0.131)\end{array}$ & $\begin{array}{c}0.180 \\
(0.398)\end{array}$ \\
\hline Private(0/1) & $\begin{array}{c}0.175^{* * *} \\
(0.002)\end{array}$ & $\begin{array}{c}0.163 * * * \\
(0.004)\end{array}$ & $\begin{array}{l}0.141^{* *} \\
(0.012)\end{array}$ & $\begin{array}{l}0.141^{* *} \\
(0.012)\end{array}$ & $\begin{array}{c}0.180^{* * *} \\
(0.001)\end{array}$ \\
\hline Private credit/GDP & $\begin{array}{c}0.079 \\
(0.334)\end{array}$ & $\begin{array}{c}0.002 \\
(0.989)\end{array}$ & $\begin{array}{c}0.004 \\
(0.964)\end{array}$ & $\begin{array}{c}0.064 \\
(0.453)\end{array}$ & $\begin{array}{l}-0.056 \\
(0.504)\end{array}$ \\
\hline GDP per capita & $\begin{array}{l}0.0580 \\
(0.263)\end{array}$ & $\begin{array}{c}0.156^{* * *} \\
(0.004)\end{array}$ & $\begin{array}{c}0.180^{* * *} \\
(0.001)\end{array}$ & $\begin{array}{c}0.143 * * * \\
(0.006)\end{array}$ & $\begin{array}{c}0.147^{* * *} \\
(0.004)\end{array}$ \\
\hline Industry \& year dummies & Yes & Yes & Yes & Yes & Yes \\
\hline $\mathrm{N}$ & 3,001 & 3,001 & 3,001 & 3,001 & 3,001 \\
\hline $\operatorname{Adj} \cdot R^{2}$ & 0.257 & 0.235 & 0.239 & 0.235 & 0.254 \\
\hline
\end{tabular}




\section{Table 3}

\section{Corporate cash holdings and government quality: City-level regressions}

The table reports results from regressing logged cash ratio on government quality at the city level. The other variables are defined in Appendix 1. Standard errors (clustered at the city level) that are robust to heteroskedasticity and within-city serial correlation are used in computing $p$-value (in parentheses). *, **, ***: statistically significantly different from zero at the $0.10,0.05$ and 0.01 level (two-tailed), respectively. The coefficients of the constant, year and industry dummies are omitted for brevity.

\begin{tabular}{|c|c|c|c|c|c|}
\hline $\mathrm{Y}=\mathrm{Ln}$ (cash ratio) & 1 & 2 & 3 & 4 & 5 \\
\hline Property rights protection & $\begin{array}{c}-0.180 * * * \\
(0.000)\end{array}$ & & & & \\
\hline Government efficiency & & $\begin{array}{c}-0.962 * * * \\
(0.004)\end{array}$ & & & \\
\hline Lightness of tax burden & & & $\begin{array}{c}-0.957^{*} \\
(0.089)\end{array}$ & & \\
\hline Travel and entertainment cost & & & & $\begin{array}{c}-0.340 * * * \\
(0.004)\end{array}$ & \\
\hline Aggregate government quality & & & & & $\begin{array}{c}-0.178 * * * \\
(0.000)\end{array}$ \\
\hline NWC & $\begin{array}{c}0.203 \\
(0.679)\end{array}$ & $\begin{array}{c}0.272 \\
(0.599)\end{array}$ & $\begin{array}{c}0.259 \\
(0.613)\end{array}$ & $\begin{array}{c}0.215 \\
(0.669)\end{array}$ & $\begin{array}{c}0.205 \\
(0.682)\end{array}$ \\
\hline Firm size & $\begin{array}{c}0.026 \\
(0.860)\end{array}$ & $\begin{array}{c}0.009 \\
(0.955)\end{array}$ & $\begin{array}{c}0.020 \\
(0.893)\end{array}$ & $\begin{array}{c}0.049 \\
(0.729)\end{array}$ & $\begin{array}{l}-0.015 \\
(0.923)\end{array}$ \\
\hline Leverage & $\begin{array}{l}-0.215 \\
(0.671)\end{array}$ & $\begin{array}{c}-0.311 \\
(0.567)\end{array}$ & $\begin{array}{l}-0.336 \\
(0.529)\end{array}$ & $\begin{array}{c}-0.174 \\
(0.739)\end{array}$ & $\begin{array}{l}-0.325 \\
(0.531)\end{array}$ \\
\hline Q & $\begin{array}{c}0.257 \\
(0.267)\end{array}$ & $\begin{array}{c}0.262 \\
(0.263)\end{array}$ & $\begin{array}{c}0.271 \\
(0.247)\end{array}$ & $\begin{array}{c}0.282 \\
(0.232)\end{array}$ & $\begin{array}{c}0.276 \\
(0.220)\end{array}$ \\
\hline Capex & $\begin{array}{l}-1.336 \\
(0.193)\end{array}$ & $\begin{array}{l}-1.760 \\
(0.109)\end{array}$ & $\begin{array}{l}-1.525 \\
(0.154)\end{array}$ & $\begin{array}{l}-1.383 \\
(0.178)\end{array}$ & $\begin{array}{l}-1.474 \\
(0.185)\end{array}$ \\
\hline Cash flow & $\begin{array}{l}1.552^{*} \\
(0.086)\end{array}$ & $\begin{array}{c}1.389 \\
(0.138)\end{array}$ & $\begin{array}{c}1.410 \\
(0.134)\end{array}$ & $\begin{array}{c}1.619 * \\
(0.0917)\end{array}$ & $\begin{array}{c}1.394 \\
(0.139)\end{array}$ \\
\hline Dividend payout $(0 / 1)$ & $\begin{array}{c}0.509 * * \\
(0.019)\end{array}$ & $\begin{array}{c}0.485 * * \\
(0.033)\end{array}$ & $\begin{array}{c}0.470 * * \\
(0.035)\end{array}$ & $\begin{array}{c}0.550 * * \\
(0.011)\end{array}$ & $\begin{array}{c}0.486 * * \\
(0.029)\end{array}$ \\
\hline Subsidy & $\begin{array}{c}53.474 * * \\
(0.037)\end{array}$ & $\begin{array}{c}57.780^{* *} \\
(0.024)\end{array}$ & $\begin{array}{c}60.708 * * \\
(0.016)\end{array}$ & $\begin{array}{c}59.318 * * \\
(0.018)\end{array}$ & $\begin{array}{c}55.212 * * \\
(0.020)\end{array}$ \\
\hline Ownership wedge & $\begin{array}{l}-0.647 \\
(0.557)\end{array}$ & $\begin{array}{c}0.057 \\
(0.960)\end{array}$ & $\begin{array}{l}-0.052 \\
(0.963)\end{array}$ & $\begin{array}{c}0.113 \\
(0.924)\end{array}$ & $\begin{array}{l}-0.727 \\
(0.511)\end{array}$ \\
\hline Private $(0 / 1)$ & $\begin{array}{c}0.253 \\
(0.372)\end{array}$ & $\begin{array}{c}0.258 \\
(0.375)\end{array}$ & $\begin{array}{c}0.149 \\
(0.592)\end{array}$ & $\begin{array}{c}0.128 \\
(0.646)\end{array}$ & $\begin{array}{c}0.262 \\
(0.342)\end{array}$ \\
\hline Private credit/GDP & $\begin{array}{c}-0.073 \\
(0.703)\end{array}$ & $\begin{array}{c}-0.429 * * \\
(0.025)\end{array}$ & $\begin{array}{c}-0.483 * * \\
(0.019)\end{array}$ & $\begin{array}{c}-0.388 * \\
(0.065)\end{array}$ & $\begin{array}{l}-0.295 \\
(0.108)\end{array}$ \\
\hline GDP per capita & $\begin{array}{c}0.104 \\
(0.471)\end{array}$ & $\begin{array}{c}0.137 \\
(0.367)\end{array}$ & $\begin{array}{c}0.207 \\
(0.195)\end{array}$ & $\begin{array}{c}0.152 \\
(0.312)\end{array}$ & $\begin{array}{c}0.220 \\
(0.142)\end{array}$ \\
\hline Industry \& year dummies & Yes & Yes & Yes & Yes & Yes \\
\hline $\mathrm{N}$ & 324 & 324 & 324 & 324 & 324 \\
\hline $\operatorname{Adj} . R^{2}$ & 0.237 & 0.200 & 0.166 & 0.182 & 0.234 \\
\hline
\end{tabular}




\section{Table 4}

\section{Government quality and financial constraints: Firm-level results}

The table shows how government quality mitigates financial constraints. The dependent variable is capital expenditure/year-beginning assets. The other variables are defined in Appendix 1. Standard errors (clustered at the firm level) that are robust to both cross-sectional heteroskedasticity and within-firm serial correlation are used in computing $p$-value (in parentheses). $*, * *, * * *$ statistically significantly different from zero at the $0.10,0.05$ and 0.01 level (two-tailed), respectively. The coefficients of the constant, year and industry dummies are omitted for brevity.

\begin{tabular}{|c|c|c|c|c|c|}
\hline $\mathrm{Y}=\mathrm{Capx}_{\mathrm{t}} / \operatorname{assets}_{\mathrm{t}-1}$ & 1 & 2 & 3 & 4 & 5 \\
\hline Cash flow & $\begin{array}{c}0.104 * * * \\
(0.000)\end{array}$ & $\begin{array}{c}0.099 * * * \\
(0.000)\end{array}$ & $\begin{array}{c}0.099 * * * \\
(0.000)\end{array}$ & $\begin{array}{c}0.098^{* * *} \\
(0.000)\end{array}$ & $\begin{array}{c}0.101^{* * *} \\
(0.000)\end{array}$ \\
\hline Property rights protection & $\begin{array}{c}0.009 \\
(0.235)\end{array}$ & & & & \\
\hline Government efficiency & & $\begin{array}{l}-0.003 \\
(0.595)\end{array}$ & & & \\
\hline Lightness of tax burden & & & $\begin{array}{c}0.004 \\
(0.602)\end{array}$ & & \\
\hline Government cleanliness & & & & $\begin{array}{c}0.002 \\
(0.404)\end{array}$ & \\
\hline Aggregate government quality & & & & & $\begin{array}{c}0.001 \\
(0.246)\end{array}$ \\
\hline $\begin{array}{l}\text { Property rights protection * } \\
\text { Cash flow }\end{array}$ & $\begin{array}{c}-0.304 * * * \\
(0.000)\end{array}$ & & & & \\
\hline $\begin{array}{l}\text { Government efficiency * Cash } \\
\text { flow }\end{array}$ & & $\begin{array}{c}-0.029 * * * \\
(0.000)\end{array}$ & & & \\
\hline $\begin{array}{l}\text { Lightness of tax burden * } \\
\text { Cash flow }\end{array}$ & & & $\begin{array}{c}-0.196^{* * *} \\
(0.009)\end{array}$ & & \\
\hline $\begin{array}{l}\text { Travel and entertainment } \\
\text { cost* }^{*} \text { Cash flow }\end{array}$ & & & & $\begin{array}{l}-0.036^{*} \\
(0.064)\end{array}$ & \\
\hline $\begin{array}{l}\text { Aggregate government quality } \\
* \text { Cash flow }\end{array}$ & & & & & $\begin{array}{c}-0.024 * * * \\
(0.000)\end{array}$ \\
\hline Q & $\begin{array}{c}0.019 * * * \\
(0.000)\end{array}$ & $\begin{array}{c}0.019 * * * \\
(0.000)\end{array}$ & $\begin{array}{c}0.019 * * * \\
(0.000)\end{array}$ & $\begin{array}{c}0.019 * * * \\
(0.000)\end{array}$ & $\begin{array}{c}0.019 * * * \\
(0.000)\end{array}$ \\
\hline Firm size & $\begin{array}{c}0.012 * * * \\
(0.000)\end{array}$ & $\begin{array}{c}0.012 * * * \\
(0.000)\end{array}$ & $\begin{array}{c}0.013^{* * *} \\
(0.000)\end{array}$ & $\begin{array}{c}0.013 * * * \\
(0.000)\end{array}$ & $\begin{array}{c}0.013^{* * *} \\
(0.000)\end{array}$ \\
\hline Leverage & $\begin{array}{l}-0.003 \\
(0.477)\end{array}$ & $\begin{array}{l}-0.001 \\
(0.781)\end{array}$ & $\begin{array}{l}-0.002 \\
(0.708)\end{array}$ & $\begin{array}{l}-0.002 \\
(0.633)\end{array}$ & $\begin{array}{l}-0.003 \\
(0.571)\end{array}$ \\
\hline Industry \& year dummies & Yes & Yes & Yes & Yes & Yes \\
\hline $\mathrm{N}$ & 3,060 & 3,060 & 3,060 & 3,060 & 3,060 \\
\hline Adj. $R^{2}$ & 0.168 & 0.164 & 0.166 & 0.165 & 0.167 \\
\hline
\end{tabular}


Table 5

\section{Government quality and financial constraints: City-level results}

The table reports results from regressing the natural logarithm of one plus estimated investment-cash flow sensitivity on government quality at the city level. City-level investment-cash flow sensitivity is the regression coefficient of cash flow estimated from regressing capital expenditure/year-beginning assets on cash flow/year-beginning assets and lagged Q using all sample firms in a city (see McLean et al., 2011). Firm-level controls are average across all sample firms in a city. The other variables are defined in Appendix 1. Standard errors (clustered at the city level) that are robust to both cross-sectional heteroskedasticity and within-city serial correlation used in computing p-value (in parentheses). ${ }^{*}, * *, * * *$ : statistically significantly different from zero at the $0.10,0.05$ and 0.01 level (two-tailed), respectively. The coefficients of the constant, year and industry dummies are omitted for brevity.

\begin{tabular}{|c|c|c|c|c|c|}
\hline & 1 & 2 & 3 & 4 & 5 \\
\hline \multirow[t]{2}{*}{ Property rights protection } & $-0.821 * * *$ & & & & \\
\hline & $(0.000)$ & & & & \\
\hline \multirow[t]{2}{*}{ Government efficiency } & & $-0.225 * *$ & & & \\
\hline & & $(0.012)$ & & & \\
\hline \multirow[t]{2}{*}{ Lightness of tax burden } & & & $-0.412 * *$ & & \\
\hline & & & $(0.023)$ & & \\
\hline \multirow[t]{2}{*}{ Government cleanliness } & & & & $-0.090 *$ & \\
\hline & & & & $(0.055)$ & \\
\hline \multirow[t]{2}{*}{ Aggregate government quality } & & & & & $-0.071 * * *$ \\
\hline & & & & & $(0.000)$ \\
\hline \multirow[t]{2}{*}{ Firm size } & 0.034 & 0.020 & 0.027 & 0.047 & 0.008 \\
\hline & $(0.432)$ & $(0.672)$ & $(0.585)$ & $(0.359)$ & $(0.853)$ \\
\hline \multirow[t]{2}{*}{ Leverage } & $-0.327 * * *$ & $-0.397 * * *$ & $-0.374 * * *$ & $-0.347 * * *$ & $-0.372 * * *$ \\
\hline & $(0.000)$ & $(0.000)$ & $(0.000)$ & $(0.000)$ & $(0.000)$ \\
\hline \multirow[t]{2}{*}{ GDP per capita } & -0.003 & -0.042 & -0.008 & -0.046 & 0.025 \\
\hline & $(0.932)$ & $(0.373)$ & $(0.873)$ & $(0.322)$ & $(0.516)$ \\
\hline Industry \& year dummies & Yes & Yes & Yes & Yes & Yes \\
\hline $\mathrm{N}$ & 264 & 264 & 264 & 264 & 264 \\
\hline Adj. $R^{2}$ & 0.402 & 0.121 & 0.127 & 0.118 & 0.292 \\
\hline
\end{tabular}




\section{Table 6}

\section{An alternative measure of financial constraints}

The table shows how government quality mitigates financial constraints measured by the sensitivity of cash to cash flows. The dependent variable is change in cash ratio. The other variables are defined in Appendix 1. Standard errors (clustered at the firm level) that are robust to both cross-sectional heteroskedasticity and within-firm serial correlation used in computing $p$-value (in parentheses). ${ }^{*}, * *, * * *$ statistically significantly different from zero at the $0.10,0.05$ and 0.01 level (two-tailed), respectively. The coefficients of the constant, year and industry dummies are omitted for brevity.

\begin{tabular}{|c|c|c|c|c|c|}
\hline $\mathrm{Y}=\Delta$ cash ratio & 1 & 2 & 3 & 4 & 5 \\
\hline Cash flow & $\begin{array}{c}0.204 * * * \\
(0.000)\end{array}$ & $\begin{array}{l}0.192 * * * \\
(0.000)\end{array}$ & $\begin{array}{l}0.194 * * * \\
(0.000)\end{array}$ & $\begin{array}{l}0.197 * * * \\
(0.000)\end{array}$ & $\begin{array}{c}0.202^{* * * *} \\
(0.000)\end{array}$ \\
\hline $\begin{array}{l}\text { Property rights protection * Cash } \\
\text { flow }\end{array}$ & $\begin{array}{c}-0.400^{* *} \\
(0.036)\end{array}$ & & & & \\
\hline $\begin{array}{l}\text { Government efficiency } * \text { Cash } \\
\text { flow }\end{array}$ & & $\begin{array}{l}-0.179^{*} \\
(0.098)\end{array}$ & & & \\
\hline $\begin{array}{l}\text { Lightness of tax burden * Cash } \\
\text { flow }\end{array}$ & & & $\begin{array}{l}-0.292^{*} \\
(0.083)\end{array}$ & & \\
\hline $\begin{array}{l}\text { Government cleanliness*Cash } \\
\text { flow }\end{array}$ & & & & $\begin{array}{c}-0.015^{* * *} \\
(0.000)\end{array}$ & \\
\hline Aggregate government quality * & & & & & \\
\hline Cash flow & & & & & $\begin{array}{c}-0.007 * * * \\
(0.000)\end{array}$ \\
\hline Property rights protection & $\begin{array}{c}-0.083 * * * \\
(0.000)\end{array}$ & & & & \\
\hline Government efficiency & & $\begin{array}{l}-0.018^{*} \\
(0.065)\end{array}$ & & & \\
\hline Lightness of tax burden & & & $\begin{array}{c}-0.046^{* * *} \\
(0.002)\end{array}$ & & \\
\hline Travel and entertainment & & & & $\begin{array}{c}-0.094 * * \\
(0.026)\end{array}$ & \\
\hline Aggregate government quality & & & & & $\begin{array}{c}-0.043 * * \\
(0.022)\end{array}$ \\
\hline Firm size & $\begin{array}{c}0.007 * * * \\
(0.005)\end{array}$ & $\begin{array}{c}0.008^{* * *} \\
(0.003)\end{array}$ & $\begin{array}{c}0.009 * * * \\
(0.001)\end{array}$ & $\begin{array}{c}0.009^{* * *} \\
(0.001)\end{array}$ & $\begin{array}{c}0.007 * * * \\
(0.006)\end{array}$ \\
\hline Q & $\begin{array}{l}0.011 * * \\
(0.015)\end{array}$ & $\begin{array}{l}0.011^{* *} \\
(0.012)\end{array}$ & $\begin{array}{c}0.012 * * \\
(0.011)\end{array}$ & $\begin{array}{l}0.011 * * \\
(0.012)\end{array}$ & $\begin{array}{l}0.011^{* *} \\
(0.016)\end{array}$ \\
\hline Capex & $\begin{array}{c}-0.385^{* * *} \\
(0.000)\end{array}$ & $\begin{array}{c}-0.383 * * * \\
(0.000)\end{array}$ & $\begin{array}{c}-0.383 * * * \\
(0.000)\end{array}$ & $\begin{array}{c}-0.382 * * * \\
(0.000)\end{array}$ & $\begin{array}{c}-0.383 * * * \\
(0.000)\end{array}$ \\
\hline$\Delta \mathrm{NWC}$ & $\begin{array}{c}-0.329 * * * \\
(0.000)\end{array}$ & $\begin{array}{c}-0.330 * * * \\
(0.000)\end{array}$ & $\begin{array}{c}-0.331 * * * \\
(0.000)\end{array}$ & $\begin{array}{c}-0.331 * * * \\
(0.000)\end{array}$ & $\begin{array}{c}-0.328 * * * \\
(0.000)\end{array}$ \\
\hline SDebt & $\begin{array}{c}-0.178^{* * *} \\
(0.000)\end{array}$ & $\begin{array}{c}-0.178^{* * *} \\
(0.000)\end{array}$ & $\begin{array}{c}-0.179^{* * *} \\
(0.000)\end{array}$ & $\begin{array}{c}-0.177 * * * \\
(0.000)\end{array}$ & $\begin{array}{c}-0.177^{* * *} \\
(0.000)\end{array}$ \\
\hline Industry and year dummies & Yes & Yes & Yes & Yes & Yes \\
\hline $\mathrm{N}$ & 3,060 & 3,060 & 3,060 & 3,060 & 3,060 \\
\hline $\operatorname{Adj} . R^{2}$ & 0.184 & 0.173 & 0.175 & 0.176 & 0.181 \\
\hline
\end{tabular}


Table 7

\section{Government quality and financing channels}

This table reports the regression results on the relationship between government quality and financing channels. The dependent variables are financing channels in the first row. All variables are defined in Appendix 1. Standard errors (clustered at the firm level in Panel A and at the city level in Panel B) that are robust to both cross-sectional heteroskedasticity and within-firm serial correlation used in computing $p$-value (in parentheses). ${ }^{*}, * *, * * *$ : statistically significantly different from zero at the $0.10,0.05$ and 0.01 level (two-tailed), respectively. The coefficients of the constant, year and industry dummies are omitted for brevity.

\begin{tabular}{|c|c|c|c|c|}
\hline Panel A & & & & \\
\hline $\mathrm{Y}=$ & Bank Loan & Bank Loan & $\begin{array}{l}\text { Accounts } \\
\text { payable }\end{array}$ & Accounts payable \\
\hline Aggregate government quality & $\begin{array}{c}0.007 * * * \\
(0.000)\end{array}$ & $\begin{array}{c}0.007^{* * *} \\
(0.000)\end{array}$ & $\begin{array}{c}0.004 * * * \\
(0.000)\end{array}$ & $\begin{array}{c}0.004 * * * \\
(0.000)\end{array}$ \\
\hline GDP growth & $\begin{array}{c}-0.018 * * * \\
(0.000)\end{array}$ & $\begin{array}{c}-0.023 * * * \\
(0.001)\end{array}$ & $\begin{array}{c}0.010 * * * \\
(0.000)\end{array}$ & $\begin{array}{l}0.005^{*} \\
(0.087)\end{array}$ \\
\hline Firm size & & $\begin{array}{c}0.007 \\
(0.534)\end{array}$ & & $\begin{array}{c}0.014 * * * \\
(0.005)\end{array}$ \\
\hline Industry median leverage & & $\begin{array}{c}0.376^{* *} \\
(0.038)\end{array}$ & & $\begin{array}{c}0.026 \\
(0.698)\end{array}$ \\
\hline Q & & $\begin{array}{c}0.047 \\
(0.255)\end{array}$ & & $\begin{array}{c}0.021 \\
(0.101)\end{array}$ \\
\hline Industry \& year dummies & Yes & Yes & Yes & Yes \\
\hline $\mathrm{N}$ & 3,073 & 3,073 & 3,073 & 3,073 \\
\hline Adj. $R^{2}$ & 0.065 & 0.067 & 0.238 & 0.241 \\
\hline Panel B & & & & \\
\hline $\mathrm{Y}=$ & Contracted FDI & Contracted FDI & Realized FDI & Realized FDI \\
\hline Aggregate government quality & $\begin{array}{c}0.182 * * \\
(0.010)\end{array}$ & $\begin{array}{c}0.177 * * * \\
(0.008)\end{array}$ & $\begin{array}{c}0.170^{* *} \\
(0.016)\end{array}$ & $\begin{array}{c}0.168 * * \\
(0.011)\end{array}$ \\
\hline GDP growth & $\begin{array}{c}1.806^{* * *} \\
(0.000)\end{array}$ & $\begin{array}{c}1.554 * * * \\
(0.000)\end{array}$ & $\begin{array}{c}1.981 * * * \\
(0.000)\end{array}$ & $\begin{array}{c}1.768 * * * \\
(0.000)\end{array}$ \\
\hline Road & & $\begin{array}{c}0.058 \\
(0.666)\end{array}$ & & $\begin{array}{c}0.053 \\
(0.657)\end{array}$ \\
\hline Population & & $\begin{array}{c}0.139 \\
(0.574)\end{array}$ & & $\begin{array}{c}0.108 \\
(0.700)\end{array}$ \\
\hline Education expenditure & & $\begin{array}{c}0.474 * * * \\
(0.000)\end{array}$ & & $\begin{array}{c}0.417 * * * \\
(0.004)\end{array}$ \\
\hline Unemployment & & $\begin{array}{l}-0.009 \\
(0.927)\end{array}$ & & $\begin{array}{c}0.006 \\
(0.952)\end{array}$ \\
\hline Industry \& year dummies & Yes & Yes & Yes & Yes \\
\hline $\mathrm{N}$ & 308 & 308 & 307 & 307 \\
\hline Adj. $R^{2}$ & 0.372 & 0.424 & 0.395 & 0.431 \\
\hline
\end{tabular}




\section{Table 8}

\section{Government quality and cash holdings: SOEs vs. Private firms}

The table shows how the effect of government quality measures on firms' cash holdings differs in SOEs and private firms (based on ultimate ownership). The dependent variable is logged cash ratio. All variables are defined in Appendix 1. Standard errors (clustered at the firm level) that are robust to both cross-sectional heteroskedasticity and within-firm serial correlation are used in computing $p$-value (in parentheses). ${ }^{*}, * *, * *$ : statistically significantly different from zero at the $0.10,0.05$ and 0.01 level (two-tailed), respectively. The coefficients of the constant, year and industry dummies are omitted for brevity.

\begin{tabular}{|c|c|c|c|c|c|}
\hline $\mathrm{Y}=\mathrm{Ln}($ cash ratio $)$ & 1 & 2 & 3 & 4 & 5 \\
\hline Property rights protection & $\begin{array}{c}-0.945 * * * \\
(0.000)\end{array}$ & & & & \\
\hline Government efficiency & & $\begin{array}{c}-0.321^{* *} \\
(0.018)\end{array}$ & & & \\
\hline Lightness of tax burden & & & $\begin{array}{c}-4.680^{* *} \\
(0.024)\end{array}$ & & \\
\hline Travel and entertainment cost & & & & $\begin{array}{c}-0.158 * * * \\
(0.003)\end{array}$ & \\
\hline Aggregate government quality & & & & & $\begin{array}{c}-0.080 * * * \\
(0.000)\end{array}$ \\
\hline Private $(0 / 1)$ & $\begin{array}{c}0.567 * * * \\
(0.006)\end{array}$ & $\begin{array}{c}0.077 \\
(0.656)\end{array}$ & $\begin{array}{l}-0.223 \\
(0.269)\end{array}$ & $\begin{array}{c}0.177 \\
(0.206)\end{array}$ & $\begin{array}{c}0.504^{* * *} \\
(0.000)\end{array}$ \\
\hline $\begin{array}{l}\text { Property rights protection* } \\
\text { Private }\end{array}$ & $\begin{array}{l}-0.636^{*} \\
(0.063)\end{array}$ & & & & \\
\hline $\begin{array}{l}\text { Government efficiency * } \\
\text { Private }\end{array}$ & & $\begin{array}{l}-0.129 \\
(0.585)\end{array}$ & & & \\
\hline $\begin{array}{l}\text { Lightness of tax burden * } \\
\text { Private }\end{array}$ & & & $\begin{array}{l}-7.473^{*} \\
(0.058)\end{array}$ & & \\
\hline $\begin{array}{l}\text { Travel and entertainment cost * } \\
\text { Private }\end{array}$ & & & & $\begin{array}{c}0.028 \\
(0.768)\end{array}$ & \\
\hline $\begin{array}{l}\text { Aggregate government quality } \\
\text { * Private }\end{array}$ & & & & & $\begin{array}{c}-0.079 * * \\
(0.022)\end{array}$ \\
\hline $\begin{array}{l}\text { Other firm- and city-level } \\
\text { controls as in Table } 2\end{array}$ & Yes & Yes & Yes & Yes & Yes \\
\hline Industry \& year dummies & Yes & Yes & Yes & Yes & Yes \\
\hline $\mathrm{N}$ & 3,001 & 3,001 & 3,001 & 3,001 & 3,001 \\
\hline Adj. $R^{2}$ & 0.259 & 0.236 & 0.241 & 0.235 & 0.257 \\
\hline
\end{tabular}




\section{Table 9}

\section{Government quality and cash holdings: Instrumental variable estimation}

The table presents the 2SLS regression results. In the first stage, the dependent variable is aggregate government quality and the (excluded) instruments are green space, air quality, and infant mortality. In the second stage, logged cash ratio is regressed on the predicted aggregate government quality from the first stage regression. Shea's (1997) partial $R^{2}$ is a measure of IV relevance. First-stage $F$-test is the test of excluded IV in the first-stage regression. Hansen's $\mathrm{J}$ tests over-identification and has a $p$-value $=0.489$, suggesting that our instruments also satisfy the exogeneity condition.

\begin{tabular}{|c|c|c|}
\hline \multirow[b]{2}{*}{$\mathrm{Y}=$} & First stage & Second stage \\
\hline & Aggregate government quality & Cash ratio \\
\hline Aggregate government quality & & $\begin{array}{c}-0.142 * * * \\
(0.000)\end{array}$ \\
\hline Green space & $\begin{array}{c}0.030 * * * \\
(0.000)\end{array}$ & \\
\hline Air quality & $\begin{array}{c}0.545 * * * \\
(0.000)\end{array}$ & \\
\hline Infant mortality & $\begin{array}{c}0.037 * * \\
(0.044)\end{array}$ & \\
\hline NWC & $\begin{array}{l}-0.183 \\
(0.245)\end{array}$ & $\begin{array}{c}-0.537 * * * \\
(0.000)\end{array}$ \\
\hline Firm size & $\begin{array}{c}-0.054 \\
(0.179)\end{array}$ & $\begin{array}{l}-0.007 \\
(0.733)\end{array}$ \\
\hline Leverage & $\begin{array}{c}0.296 \\
(0.110)\end{array}$ & $\begin{array}{c}-1.204 * * * \\
(0.000)\end{array}$ \\
\hline Q & $\begin{array}{c}-0.138 * \\
(0.083)\end{array}$ & $\begin{array}{c}0.226^{* * *} \\
(0.000)\end{array}$ \\
\hline Capex & $\begin{array}{c}0.291 \\
(0.512)\end{array}$ & $\begin{array}{c}-0.663 * * * \\
(0.006)\end{array}$ \\
\hline Cash flow & $\begin{array}{c}0.396 \\
(0.138)\end{array}$ & $\begin{array}{c}1.326 * * * \\
(0.000)\end{array}$ \\
\hline Dividend payout $(0 / 1)$ & $\begin{array}{c}0.082 \\
(0.272)\end{array}$ & $\begin{array}{c}0.357 * * * \\
(0.000)\end{array}$ \\
\hline Subsidy & $\begin{array}{c}4.832 \\
(0.392)\end{array}$ & $\begin{array}{c}2.943 \\
(0.444)\end{array}$ \\
\hline Ownership wedge & $\begin{array}{c}-1.629 * * * \\
(0.000)\end{array}$ & $\begin{array}{c}0.118 \\
(0.464)\end{array}$ \\
\hline Private $(0 / 1)$ & $\begin{array}{c}0.321 * * * \\
(0.000)\end{array}$ & $\begin{array}{c}0.193 * * * \\
(0.000)\end{array}$ \\
\hline Private credit/GDP & $\begin{array}{c}-0.397 * * * \\
(0.004)\end{array}$ & $\begin{array}{l}-0.091 \\
(0.145)\end{array}$ \\
\hline GDP per capita & $\begin{array}{c}0.149 \\
(0.257)\end{array}$ & $\begin{array}{c}0.155 * * * \\
(0.000)\end{array}$ \\
\hline Industry \& year dummies & Yes & Yes \\
\hline First-stage Shea's partial $\mathrm{R}^{2}$ & 0.241 & \\
\hline First-stage $F$-test ( $p$-value) & 0.000 & \\
\hline Hansen J-test of over-identification ( $p$-value) & 0.489 & \\
\hline $\mathrm{N}$ & 3,001 & 3,001 \\
\hline Second-stage adj. $\mathrm{R}^{2}$ & & 0.251 \\
\hline
\end{tabular}




\section{Table 10}

\section{Testing "the twin agency problem"}

This table reports the regression results on the impact of "the twin agency problem" on cash holdings. The dependent variable is cash ratio. The variables are defined in Appendix 1. Standard errors (clustered at the firm level) that are robust to both cross-sectional heteroskedasticity and within-firm serial correlation are used in computing $p$-value (in parentheses). $*, * *, * * *$ : statistically significantly different from zero at the $0.10,0.05$ and 0.01 level (two-tailed), respectively. The coefficients of the constant, year and industry dummies are omitted for brevity.

\begin{tabular}{|c|c|c|c|}
\hline $\mathrm{Y}=\mathrm{Ln}($ cash ratio $)$ & 1 & 2 & 3 \\
\hline \multirow[t]{2}{*}{ Ownership wedge } & $0.365^{*}$ & 0.180 & $0.521 * *$ \\
\hline & $(0.089)$ & $(0.398)$ & $(0.030)$ \\
\hline \multirow[t]{2}{*}{ Aggregate government quality (AGQ) } & & $-0.107 * * *$ & \\
\hline & & $(0.000)$ & \\
\hline \multirow[t]{2}{*}{ AGQ > sample median (0/1) (High AGQ) } & & & $-0.262 * * *$ \\
\hline & & & $(0.000)$ \\
\hline \multirow[t]{2}{*}{ High AGQ * Ownership wedge } & & & $-0.773 *$ \\
\hline & & & $(0.072)$ \\
\hline \multirow[t]{2}{*}{ NWC } & $-0.529 * * *$ & $-0.535 * * *$ & $-0.560 * * *$ \\
\hline & $(0.000)$ & $(0.000)$ & $(0.000)$ \\
\hline \multirow[t]{2}{*}{ Firm size } & 0.003 & -0.005 & -0.003 \\
\hline & $(0.917)$ & $(0.879)$ & $(0.911)$ \\
\hline \multirow[t]{2}{*}{ Leverage } & $-1.256 * * *$ & $-1.217 * * *$ & $-1.246 * * *$ \\
\hline & $(0.000)$ & $(0.000)$ & $(0.000)$ \\
\hline \multirow[t]{2}{*}{ Q } & $0.234 * * *$ & $0.228 * * *$ & $0.232 * * *$ \\
\hline & $(0.000)$ & $(0.000)$ & $(0.000)$ \\
\hline \multirow[t]{2}{*}{ Capex } & $-0.689 * *$ & $-0.669 * *$ & $-0.641 * *$ \\
\hline & $(0.015)$ & $(0.018)$ & $(0.023)$ \\
\hline \multirow[t]{2}{*}{ Cash flow } & $1.227 * * *$ & $1.301 * * *$ & $1.256^{* * *}$ \\
\hline & $(0.000)$ & $(0.000)$ & $(0.000)$ \\
\hline \multirow[t]{2}{*}{ Dividend payout $(0 / 1)$} & $0.337 * * *$ & $0.352 * * *$ & $0.341 * * *$ \\
\hline & $(0.000)$ & $(0.000)$ & $(0.000)$ \\
\hline \multirow[t]{2}{*}{ Subsidy } & 2.291 & 2.781 & 2.426 \\
\hline & $(0.656)$ & $(0.574)$ & $(0.622)$ \\
\hline \multirow[t]{2}{*}{ Private(0/1) } & $0.142^{* *}$ & $0.180^{* * *}$ & $0.164^{* * *}$ \\
\hline & $(0.012)$ & $(0.001)$ & $(0.003)$ \\
\hline \multirow[t]{2}{*}{ Private credit/GDP } & 0.052 & -0.056 & 0.024 \\
\hline & $(0.533)$ & $(0.504)$ & $(0.772)$ \\
\hline \multirow[t]{2}{*}{ GDP per capita } & $0.122 * *$ & $0.147 * * *$ & 0.073 \\
\hline & $(0.020)$ & $(0.004)$ & $(0.161)$ \\
\hline Industry \& year dummies & Yes & Yes & Yes \\
\hline $\mathrm{N}$ & 3,001 & 3,001 & 3,001 \\
\hline $\operatorname{Adj} . R^{2}$ & 0.230 & 0.254 & 0.254 \\
\hline
\end{tabular}

